\begin{abstract}
GREGORY III, SAMUEL THORNE. Differences in Sediment Organic Matter Composition and PAH Weathering Between Non-Vegetated and Recently Vegetated FuelOiled Sediments. (Under the direction of Elizabeth Guthrie Nichols and Damian Shea).

Previous results have shown a strong correlation between vegetation and dissipation of polycyclic aromatic hydrocarbon $(\mathrm{PAH})$ contamination over long time frames. Evidence of phytoremediation over shorter time frames is difficult to detect, particularly in sites where overall PAH concentrations have not begun to significantly decrease. This study assessed the impact of vegetation on a highly contaminated sediment over a short time frame in order to track the effects of plant derived organic carbon (PdOC) in a variety of sediment compartments. The Indiana Harbor Canal is an industrialized area with historic petroleum contamination of near-shore sediments. In 2002, near-shore sediments were planted with hybrid poplar and willow trees as part of a phytoremediation treatability study. Site disturbance allowed for colonization by cattails and Phragmites. In 2004, non-vegetated and vegetated oiled-shore sediments were collected and analyzed for 42 polycyclic aromatic hydrocarbons (PAHs), total organic carbon, and percent modern carbon $\left(\Delta^{14} \mathrm{C}\right.$ radiocarbon). Sediments were collected from several locations, field-composited, homogenized, sieved, and chemically fractionated. There is a significant input of modern carbon in both labile and recalcitrant fractions of vegetated sediments that is absent in the non-vegetated control. Phragmites sediments contained more modern carbon (plant carbon) and more weathered PAH ratios than willow, cattail, and non-vegetated sediments. Organic carbon-normalized PAH concentrations were greater in Phragmites humin than other sediments. Humin fractions of willow trees were more weathered than non-vegetated
\end{abstract}


humin, but modern carbon values were not always different. Cattail humin contained more modern carbon than non-vegetated humin, but only de-ashed humin was more weathered than non-vegetated de-ashed humin. Results show that sediment composition and PAH weathering indices are not indicative of reduced PAH concentrations. Instead, PAH weathering appears related to increased modern carbon (plant carbon) content. Substantial increases in modern carbon content were observed after two years of plant growth. These results suggest that $\mathrm{PdOC}$ is diffusing into a variety of sediment compartments where it may be enhancing carbon cycling and beginning to mitigate PAH concentrations. 


\title{
Differences in Sediment Organic Matter Composition and PAH Weathering Between Non-Vegetated and Recently Vegetated Fuel-Oiled Sediments
}

\author{
By
}

Samuel Thorne Gregory III

\author{
A thesis submitted to the Graduate Faculty of \\ North Carolina State University \\ In partial fulfillment of the \\ requirements for the Degree of \\ Master of Science
}

Toxicology

Raleigh, North Carolina

2007

APPROVED BY:

Dr. Elizabeth Guthrie Nichols Co-Chair of Advisory Committee
Dr. Damian Shea

Co-Chair of Advisory Committee

Dr. Chris S. Hofelt 


\section{BIOGRAPHY}

Samuel Thorne Gregory III. (or just Thorne) was born on July 17, 1980 in Wilson N.C. Being born a little early, he ended up a Cancer instead of a Virgo as was expected. His first 12 years were spent in the town of Dunn, N.C., known more for its physical location (at the intersection of 421 and I-95) than any special characteristics about the place. After spending many hours in the Dunn public library, Thorne moved to New Jersey where he received all but one year of his mandatory education before moving back to Sanford N.C. for his final year of high school. Thorne then enrolled at the University of North Carolina, like his parent and grandparents before him. He graduated in 2002 with a B.S. in chemistry but decided that the synthetic inorganic research he had been pursuing was not what he wanted to do for the rest of his life. In fact, it was the warning labels on the reagents that caught his attention, so he enrolled in the graduate program in Toxicology at NCSU. Thorne is an avid biker, runner, and a voracious reader. His previous jobs include reptile breeder, disk jockey for both FM and AM radio stations, computer repair technician, and teaching assistant. When asked what it was like to wrangle cold blooded creatures with brains the size of a pea, or about the monotony of hearing the same thing day in and day out....his teaching assistant experience is what comes to mind. 


\section{AKNOWLEDGEMENTS}

I would like to thank everyone who supported me and my research during this time. First, I would like to thank Dr. Elizabeth Nichols for taking me on as a graduate student before she had even unpacked her office and for all of her expertise and patience. I would also like to thank Dr. Damian Shea for his advice and generous laboratory contributions. Dr. Neal Blair is also deserving of acknowledgement for his isotopic expertise and willingness to answer questions that were far beneath his own understanding. A special thanks goes out to Pete Lazaro for all his laboratory expertise and patience, as well as to Steve Rock at the EPA for graciously tour guiding our sampling trips. All of the undergraduates that have assisted at one time or another: Evan Dzierzynski, Shervin Ejali, Zach Eyler, and Carter Reeb, thank you all for your time and efforts. Thanks also to Dr. Chris Hofelt for his time and assistance. I would also like to thank my family and friends who have all endured the trials and tribulations with me. Finally I would like to thank the National Science Foundation for their generous support of this and many other projects (BES-0337453). 


\section{TABLE OF CONTENTS}

$\underline{\text { Section }}$

$\underline{\text { Page \# }}$

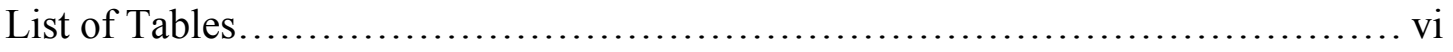

List of Figures...................................................... vii

1. LITERATURE REVIEW ............................................. 1

1.1 Polycyclic Aromatic Hydrocarbons. Risks and Accessibility.............. 1

1.2 PAHs in Soils and Sediments.................................. 2

1.3 Mediators of PAH Dissipation; the rhizosphere and associated microbial populations....................... 4

1.4 Enhanced PdOC flux into PAH contaminated sediments in response to root stress...................... 6

1.5 Field Studies of Phytoremediation of PAHs ........................ 8

1.6 Chemical Fractionation in PAH studies............................

1.7 Using Carbon Isotopic techniques to probe for PdOM sediment modification............................. 10

1.8 Phragmites australis............................................. 11

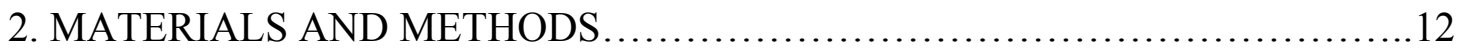

2.1 Site Description and Sampling Methods............................. 12

2.2 Sediment Fractionation.......................................... 14

$2.3 \mathrm{OM}$ Composition............................................. 15

2.4 FTIR Analysis.................................................... 16

2.5 GC/MS SIM.................................................... 16 
2.6 Statistical Analyses............................................. 16

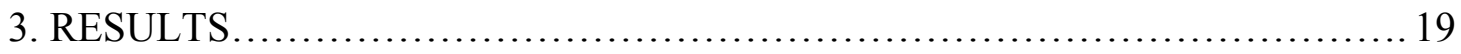

3.1 Impact of Vegetation on Sediment Composition........................ 19

3.2 PAH Concentrations in Sediment Fractions......................... 20

3.3 PAH Weathering and Sediment Composition........................ 21

3.4 Phragmites' ability to colonize contaminated sediment...................23

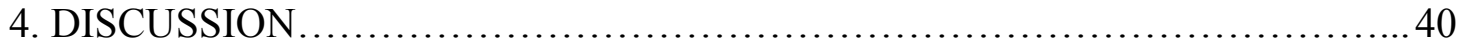

5. CONCLUSIONS ...................................................... 43

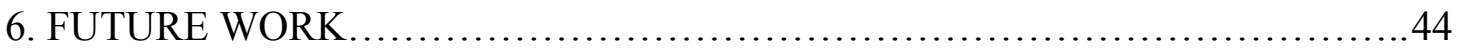

7. REFERENCES ..................................................... 46 


\section{LIST OF TABLES}

$\underline{\text { Table }}$

$\underline{\text { Page \# }}$

Table 1. Inventory of 42 Alkylated and non-Alkylated PAHs.................... 18

Table 2. Individual PAH concentrations across the study sites for Bulk Sediment.... 33

Table 3. Individual PAH concentrations across the study sites for humin............. 35

Table 4. Individual PAH concentrations across the study sites for de-ashed humin...37

Table 5. TPAH concentrations normalized to sediment mass and OC................39 


\section{LIST OF FIGURES}

$\underline{\text { Figure }}$

$\underline{\text { Page \# }}$

Figure 1. Selected FTIR spectra of Indiana Harbor Sediment Fractions............. 24

Figure 2. \%TOC and PMC of bulk sediment and humin fractions of vegetated and non-vegetated samples of Indiana Harbor Sediment.

Figure 3. Individual PAH concentrations for the non-vegetated zone for bulk sediment, humin, and de-ashed humin 26

Figure 4. Individual PAH concentrations for the phragmites dominated zone for bulk sediment, humin, and de-ashed humin.

Figure 5. Individual PAH concentrations for the cattails dominated zone for bulk sediment, humin, and de-ashed humin.

Figure 6. Individual PAH concentrations for the willow dominated zone for bulk sediment, humin, and de-ashed humin

Figure 7. Cross plots of $\mathrm{C}_{3}$-naphthalenes to $\mathrm{C}_{2}$-phenanthrenes $\left(\mathrm{N}_{3} / \mathrm{P}_{2}\right)$ alkylated PAH homologues to percent Total Organic Carbon (\% TOC) for sediment and humin fractions of vegetated and non vegetated sediments at the Indiana Harbor Canal site.

Figure 8. Cross plots of $\mathrm{C}_{3}$-naphthalenes to $\mathrm{C}_{2}$-phenanthrenes $\left(\mathrm{N}_{3} / \mathrm{P}_{2}\right)$ alkylated PAH homologues to. Percent Modern Carbon (PMC) for sediment and humin fractions of vegetated and non vegetated sediments at the Indiana Harbor Canal.

Figure 9. Phragmites australis and cattails (Typha angustifolia) growth in greenhouse containers. Plants were rooted in clean soil that was placed on top of Indiana Harbor Canal sediment. Phragmites grew around and into the oiled sediment, where as cattails did not... 


\section{CHAPTER 1. LITERATURE REVIEW}

\subsection{Polycyclic Aromatic Hydrocarbons. Risks and Accessibility}

Polycyclic Aromatic Hydrocarbons (PAHs) are persistent organic contaminants with a variety of acute, chronic, mutagenic, and carcinogenic effects (Durant et al., 1996, 1999, Cavalieri et al., 1988). PAHs are byproducts of both incomplete combustion processes, forming pyrogenic PAHs, and catagenesis reactions, creating petrogenic PAHs (Fernandes et al., 2003; Tissot et al., 1978). High concentrations of petrogenic PAHs are often found in residual soils and sediments at sites of historical petroleum transport and refining. The contaminant levels at many sites often exceed environmental regulations and can encompass large areas making them difficult to remediate with standard technologies. Alternative treatment options at PAH contaminated sites that are less invasive and expensive are of great interest to a variety of regulatory groups and private industries. One such treatment option is phytoremediation, or the use of vegetation to mitigate the environmental impacts and risks of soil and water contamination. A variety of studies have investigated plants and their associated microbial communities for the in situ treatment of organic contaminants, such as PAHs, in soils and sediments (Widdowson et al., 2005; Davis et al., 2002; Mueller et al., 2006).

The overall risk associated with any level of sediment contamination is highly dependent on the bioavailability of the compound. The more bioavailable a contaminant, the more likely it will cause a deleterious effect on any given organism. It is the structure and lipophilicity of a given compound that determines its overall bioavailability and thereby plays a major role in the efficacy of phytoremediation of the contaminant (Binet et al., 2000). More bioavailable and water soluble contaminants are generally more accessible to microorganisms and therefore more likely to be metabolized. Bioavailability also depends on the aging and 
environmental weathering of the contaminant (Hatzinger et al., 1995; Erickson et al., 1993), and the physical properties, such as organic matter and particle size, of the sediment in question (Pignatello, 1989). As contaminants age, they preferentially diffuse into sediment pores and absorb into or are adsorbed onto sediment organic matter in matrix pores where they can then be incorporated into stable soil/sediment organic matter phases (Ehlers et al., 2003).

The fraction of PAHs in sediments that are currently or potentially available to living organisms is known as the bioaccessible fraction (Semple et al., 2004). This fraction differs from the "bioavailable" fraction; bioavailability more specifically denotes the contaminant fraction that is available to cause deleterious effects to organisms when the organism is in contact with the contaminated media. This system is further complicated by dynamic inputs of new plant derived organic carbon. PdOC may enhance rates of PAH degradation by stimulating microbial activity and/or by increasing PAH bioavailability in the rhizosphere (Binet et al., 2000).

\subsection{PAHs in Soils and Sediments}

Soils and sediments are highly heterogeneous with respect to organic matter composition, carbon structures, and sorptive properties. Several researchers have evaluated the binding affinities of functionally different carbon containing compartments of sediments to non-ionic contaminants (Luthy et al., 1998; Hundal et al., 2001; Chen et al., 2005; Rockne et al., 2002). To understand the risks created by PAH contamination in soils and sediments, it is necessary to characterize the potential accessibility of PAHs in various sediment fractions.

Many components of sediment may have a significant impact on PAH sorption and therefore affect bioavailability and bioaccessibility. For example, black carbon (BC) is 
ubiquitous in many types of sediment and may compose a significant portion of lighter density fractions of sediments. $\mathrm{BC}$ is a type of $\mathrm{OC}$ created from the incomplete combustion of organic matter. Because of the highly condensed, aromatic nature of BC, it may significantly decrease bioavailability of PAHs in sediments that have high $\mathrm{BC}$ contents. Black carbon has been shown to have a much greater affinity for PAH sorption than sedimentary organic matter in general (Accardi-Dey and Gschwend, 2001).

Another dominant set of compounds, as pertains to PAH accessibility in sediment fractions, is derived from PdOC. Plant detrital material has been shown to be a strong sorbent for PAHs (Chen et al., 2005; Sachleben et al., 2004, Chefetz et al., 2000). Although PdOC is an excellent sorbent for aromatic hydrophobic contaminants, it is also most available for rapid turnover by microorganisms. PdOC may enable unavailable PAHs to diffuse into more available, labile sediment compartments. PAHs may adsorb to labile plant exudates and other plant derived compounds. Many of these compounds are rapidly metabolized by sediment microorganisms. Consequently, PAHs associated with these rapidly cycling compounds may by accessible for microbial degradation.

Interactions between sedimentary sorbates such as $\mathrm{BC}$ or PdOC can further complicate the dynamics of PAH sorption. Hong et al. (2003) analyzed sorption of PAHs in soil contaminated with lampblack and oil. BC containing low levels of PAHs demonstrated sorption similar to BC models while lampblack with high levels of PAHs demonstrated sorption similar to that expected in a coal tar mixture. When oil was added to the $\mathrm{BC}$, sorption sites were coated and sorption of $\mathrm{PAH}$ to the $\mathrm{BC}$ surface structure was diminished. This same behavior has been observed when natural organic matter is added to BC. Carter et al. (1994) found that the absorptive capacity of BC, when exposed to natural 
organic matter, was significantly reduced. This implies that a variety of competing sorbates can effectively "coat" the BC particle and reduce the number of potentially available sorptive sites for PAHs. Because BC reduces bioavailability and bioaccessibility, blocking access to BC sorptive sites would therefore result in increased PAH availability.

PdOC may also make BC-sorbed PAHs more bioaccessible. When PdOC and BC come into contact in sediments, it is reasonable to expect that PAHs may diffuse from BC into more labile PdOC. It is also possible that enhanced carbon cycling caused by labile PdOC inputs may cause BC mineralization. The mechanisms by which $\mathrm{BC}$ is transformed in sediments is poorly understood, but it is possible that overall increases in carbon cycling in sediment due to PdOC inputs may include BC mineralization. These circumstances would explain how older, more recalcitrant PAHs may be mobilized by inputs of PdOC and made more accessible for biodegradation.

\subsection{Mediators of PAH Dissipation; the rhizosphere and associated microbial populations}

The area where plant roots, plant exudates, and contaminated media physically interact is termed "the rhizosphere" (Grayston et al., 1996). Rhizosphere soil is a zone of enhanced microbial activity that is fueled by labile carbon from plant exudates. Rhizosphere soil also has enhanced microbial populations due to the physical support that root surfaces provide. Microbial populations in the rhizosphere are often 5 to 100 times that of surrounding soils (Liste and Prutz, 2006). Rhizosphere microbial populations may be responsible for enhanced degradation of PAHs in vegetated sediments. Microorganisms living in the rhizosphere that can attack and metabolize aged residues may be a primary means by which plant communities are able to dissipate weathered organic contaminants. Recent work has shown that some 
microorganisms are able to desorb and biodegrade aged contaminants from less available compartments by producing surfactants and other compounds that enhance the accessibility of weathered compounds (Park et al., 2001). PdOC may therefore enhance bioaccessibility of PAHs in the rhizosphere in 2 ways: first by acting as a more labile sorbent for PAHs, and second, by fueling the production of microbial compounds that enhance accessibility. Some studies have shown a significant effect on PAH mitigation specifically in the rhizosphere (Anderson et al 1993, Shimp et al 1993). In one particular study, PAH was sprayed on a quartz sheet in a monolayer and a root was allowed to grow over the treated surface of the sheet (Thoma et al., 2005). Fluorescence measurements quantitatively determined that PAH concentrations declined in the area of the quartz plate adjacent to the root over time. These findings suggested that the root directly contributed to PAH removal; however, whether PAH depletion occurred by physical diffusion into labile plant derived components or microbial degradation by root-associated microorganisms was unclear.

Proposed mechanisms by which PdOC may decrease levels of extractable contaminant are (1) enhanced sorption onto labile PdOC leading to accelerated sequestration, or (2) greater microbial density and activity along the root surfaces. Alternatively, a combination of these two hypotheses may be responsible; PAHs may diffuse into new labile organic carbon from more recalcitrant, mineralized compartments and become more available to microbial communities for metabolism. White et al (2003) found that addition of organic acids considerably enhance desorption of DDE from weathered soils. Low molecular weight organic acids, some of which are exuded from plant root systems to enhance mineral availability, disrupted the SOM and mediated a temporary increase in availability of organic compounds 
that were previously unavailable. Thus, release of PdOC, including organic acids, into sediments may increase PAH bioaccessibility (Brogan et al., 2003; Liste and Alexander, 2000).

Plant-derived materials demonstrate different sorptive affinities for PAHs (Salloum et al., 2002; Chen et al., 2005; Chefetz et al., 2000). Plant cuticle, an aliphatic biopolymer, has greater organic carbon sorption coefficients $\left(\mathrm{K}_{\mathrm{oc}}\right.$ values) for PAHs than lignin or cellulose (Salloum et al., 2002; Chefetz et al., 2000). Mao et al. (2002) observed that the sorption capacity of some cuticular, aliphatic plant materials correlated well with PAH sorption capacity in soils. Kukkonen et al. (2003) observed a positive correlation between rapid $\mathrm{PAH}$ desorption from sediment and the presence of plant materials such as lipids and lignin. Rockne et al. (2002) observed that sediment fractions containing course plant detrital material had greater $\log \mathrm{K}_{\mathrm{oc}}$ values for PAHs and desorbed more PAHs than other sediment fractions. Interestingly, greater desorption was observed for larger PAH analytes such as pyrene, chrysene, and benzo[a]pyrene as well as two and three ring PAHs in sediments containing plant detrital material (Shor et al., 2003).

\subsection{Enhanced PdOC flux into PAH contaminated sediments in response to root stress.}

PdOC loss to sediments and its effect on rhizomal bacterial growth is a probable

mechanism by which vegetation attenuates impacts organic contaminants in sediments. Numerous factors can have an affect on plant exudation rates, which can therefore mediate the overall impact of vegetation. For example, both plant species and plant age dramatically impact exudation by plant roots. Mature specimens of several species of dominant or co-dominant northern hardwood trees showed dramatic variations in variety and quantity of carbohydrate and organic acid exudation between species (Smith, 1976). A study by Leyval et al. (1993) also found significant 
differences in carbon exudation in vegetation depending on age. Older trees were found to exude less soluble organic carbon than trees that were less than one year old. Environmental factors can also influence the exudation rates of PdOC (Grayston 1996). Dehydration stress (Reid, 1974, 1977) also caused greater soluble carbon exudation rates. In this study, ${ }^{14} \mathrm{C}$ labeled vegetation released more carbon when their root systems were exposed to water stress. ${ }^{14} \mathrm{C}$ labeled plant compounds were also translocated to the roots in greater quantities in roots undergoing water stress. Several studies have shown that modulating temperature above and below a normal growth range can also cause enhanced exudation of carbon from roots (Husain et al., 1963; Meharg et al., 1998). Therefore, enhanced translocation and exudation of PdOC may occur as a stress reduction method to respond to non-specific root stress.

Liste et al. (2006) and Kmentová and Kummerová (2004) showed significant root stress on a wide variety of seedlings in weathered PAH contaminated soil. As PAHs cause a non specific stress on the root system, one would expect that PAH contaminated sediments would enhance exudation of PdOC. Increased PdOC could stimulate the microbial community and enhanced cometabolism of PAHs or accelerate binding activities that may decrease PAH bioaccessibility in the SOM. Either of these outcomes would have important ramifications for phytoremediation technologies and treatments in the future. This response must be shown definitively in field relevant trials. Many studies have explored the PAH-plant relationship and demonstrated that PAHs induce plant stress (Ryan et al., 1988; Liste et al., 2006). However, it is unclear if PAH contamination causes a specific response that enhances PdOC flux rather than non-specific root stress.

Microorganisms may also increase plant exudation by consuming plant exudates in the rhizosphere (Barber et al., 1977). Plants benefit from microbial turnover of root exudates and 
subsequent co-metabolism of soil organic matter, which releases nutrients and enhances soil fertility. Benefits from microbial biomass on root systems include mycorrhizal associations that cause enhanced uptake of trace elements and rhizomal bacterial that inhibit the growth of some plant pathogens (Raaijmakers. 1997).

\subsection{Field Studies of Phytoremediation of PAHs}

Field and laboratory studies of polycyclic aromatic hydrocarbon (PAH) phytoremediation have yielded mixed results with regards to PAH degradation. Sediment contaminated with petroleum sludge is often remediated with tillage and nutrient addition. This technology, called landfarming, is designed to promote microbial degradation of hazardous compounds. During landfarming, the presence of plants can cause a marked decrease in contaminant levels (Schwab and Banks, 1994). Most short term studies evaluated PAH attenuation within a single growing season after vegetated and non-vegetated soils were amended with specific PAH analytes. Some of these studies showed that vegetation did not significantly degrade PAHs relative to non-vegetated controls (Lalande et al., 2003; Mueller et al., 2006). Other studies did show significant reductions in PAH concentrations within a few months (Aprill and Sims 1990; Spriggs et al., 2005; Maila et al., 2005; Alvarez-Bernal et al., 2007; Jouneau et al., 2005). Some greenhouse studies showed that dissipation of PAHs was greater in the presence of plants than in their absence and that the uptake of PAH into plant tissues did not account for PAH attenuation. Over a four week growing period, Corgie et al. (2004) observed lower concentrations of pyrene in soil directly adjacent to plant roots relative to soil away from vegetation. Banks et al. (1999) also observed significant reductions in labeled PAH concentrations in planted soils versus non-planted soils; their tracer studies also showed that loss of PAH was not the result of abiotic sorption to root structures. Miya and 
Firestone (2001) proposed that enhanced PAH degradation in soils impacted by root exudates and root debris resulted from rhizo-stimulated heterotrophic, bacteria populations capable of PAH degradation. However, Jouanneau et al. (2005) observed less pyrene mineralization in soils amended with both plants, Phragmites australis, and a pyrene-degrading Mycobacterium bacteria compared to soils amended with only pyrene-degrading Mycobacterium bacteria.

A long-term study reported significant PAH reductions in the presence of mixed vegetation after 12 years exposure in field lysimeters (Doick et al., 2005). Significant declines in PAH concentrations were also observed in creosote-contaminated soils after three to four years of hybrid poplar growth at a former creosote facility field site (Marr et al., 2006; Widdowson et al., 2005; Pitterle et al., 2005). Declines in PAH concentrations were observed for only the two and three-ring PAH analytes at the creosote site (Widdowson et al., 2005). In another long term study, when mulberry root extracts were added to sediments aged with ${ }^{14} \mathrm{C}$-phenanthrene for 518 days, root-amended soils mineralized more phenanthrene and sequestered more ${ }^{14} \mathrm{C}$ label in humin relative to sterile controls (Kamath et al., 2005) The authors proposed that continuous addition of organic matter (mulberry exudates) enhanced phenanthrene dissipation by two possible mechanisms: (1) enhanced microbial populations that enhance biotic degradation and/or (2) increased phenanthrene partitioning into more available OM compartments via destabilization of the humic matrix.

\subsection{Chemical Fractionation in PAH studies}

Humic fractionation is a fractionation method that relies on separation of sediment constituents based on chemical behavior to probe sediment carbon structure and functional 
properties (Gregory et al 2005, Kőgel-Knabner and Zeigler 1993). Brogan et al. (2003)

showed that increasing total organic carbon content leads to decreased PAH bioavailability for microbial degradation in phenanthrene spiked sediments. Over the course of the experiment, availability also showed some correlation with fulvic acid content. Spiking sediments with fulvic acids enhanced microbial mineralization of PAHs, albeit, temporarily; mineralization increased when fulvic acid was added to soils with low fulvic acid content. Liste and Alexander (2000) found that PdOC enhanced extractable concentrations of PAH when added to sterilized soils. These findings suggest that chemically labile biogenic carbon fractions like humic and fulvic acids can alter soil/sediment organic matter and enhance PAH bioaccessibility.

Previous work has used chemical fractionation to investigate PdOC impact on PAH attenuation in labile and recalcitrant humic fractions of sediments (Neiman et al., 1998; Guthrie et al., 1999), particularly sediment and soil humin. Humin is generally defined as recalcitrant sediment material that remains in an insoluble form after alkaline treatment that removes the humic and fulvic organic acid fractions (Stevenson 1982). Humin accounts for a large portion of PAH sorption (Pan et al. 2006, Kohl and Rice. 1997), and is generally considered to desorb PAHs slower than other fractions (Dexter and Pavlou, 1978; Murphy et al., 1990, 1992).

\subsection{Using Carbon Isotopic techniques to probe for PdOM sediment modification}

Using the known natural abundances of radioactive carbon isotopes, it is possible to use carbon isotopic signatures as a probe for biological activity. Petrogenic PAH contamination is composed of plant derived carbon that has been buried for geologically significant timeframes in order to undergo the catagenetic processes involved in petroleum hydrocarbon production. These 
compounds are therefore highly depleted in unstable carbon isotopes. ${ }^{14} \mathrm{C}$ levels in petroleum hydrocarbons are extremely low and can therefore be used as a reverse tracer. Cheng et al. (1993) demonstrated that pulses of ${ }^{14} \mathrm{C}$ labeled $\mathrm{CO}_{2}$ were successfully incorporated into plant structures and the ${ }^{14} \mathrm{C}$ signature was tracked into root exudates and other PdOC in the rhizosphere.

Furthermore, this study demonstrated that, following incorporation into plant structures, evolved ${ }^{14} \mathrm{CO}_{2}$ was a by-product of microbial respiration caused by microbial ingestion and metabolism or labeled PdOC in the rhizosphere. Isotopic information on vegetated contaminated and pristine sediments are of interest when determining to what extent plants release increased amounts of PdOC when exposed to PAH contamination.

\subsection{Phragmites australis}

Phragmites australis is of particular interest in this study for several reasons. First, Phragmites is able to withstand harsh conditions and stress (Lissner et al., 1997). This species has been shown to be tolerant of high metal, phenolics, and azo dye concentrations (Davies et al., 2005). Phragmites australis has also been found at PAH-contaminated sites, and is responsible for much of the natural vegetation of these sites (Windham et al., 2001; Ye et al., 2003). Phragmites has also been shown to produce significant amounts of PdOC in sediments where it has become established (Brix et al. 2001). Ravit et al. (2006) found that Phragmites australis does not have a significant difference in microbial community diversity and functional ability when compared to Spartina alterniflora, even though there are significant differences in root structure and fine root biomass between these two wetland plants. Bacterial communities in wetlands sampled in this study were mainly a function of the sediment type and anthropogenic disturbance than plant species. 
We previously reported that the presence of plant carbon in Phragmites distillate waste sediment was associated with significant reductions of total PAH concentrations (TPAH) and with increased PAH weathering indices (Gregory et al., 2005). Reductions of [TPAH] and inputs of plant, or modern, carbon were as great if not greater in Phragmites humin fractions as Phragmites bulk sediments. At this particular site, several decades of Phragmites colonization and propagation altered the sediment organic matter (SOM) composition of distillate waste, reduced total PAH concentrations, and increased PAH weathering. Would similar changes occur after only two years of plant growth in petrogenic-contaminated sediments?

The purpose of this study was to better understand changes to PAH attenuation in vegetated sediments after only a few years of plant growth. We collected sediments from vegetated and non-vegetated areas at a site with historic fuel-oil contamination. PAH concentrations, PAH weathering indices, and organic matter composition in sediments colonized by Phragmites, cattails, or willow trees were compared to the same indices for non-vegetated sediments. We hypothesized that sediment fractions with measurable increases in plant organic matter (POM) content would likewise show measurable changes to sediment organic matter composition and PAH attenuation as indicated by more weathered PAH diagnostic ratios or reduced PAH concentrations. We hypothesize that enhanced flux of PdOC in sediment fractions is the primary mediator of PAH dissipation and should be detectable after only 2 years. 


\section{CHAPTER 2. MATERIALS AND METHODS}

\subsection{Site Description and Sampling Methods.}

The Indiana Harbor Canal (IH) is located in a heavily industrialized section of Gary, Indiana. Total petroleum hydrocarbon (TPH) concentrations range from $2 \%$ to $43 \%$ of sediment mass; eight samples of oiled-shore sediments collected in 2001 had mean PAH concentrations of 4,100 ppm (Sand Creek Consultants, Inc., 2002). Diesel fuel is the predominant petrogenic contaminant source at the site, and, for decades, workers have noticed a persistent petroleum sheen in canal waters. In 2002, several varieties of hybrid poplars and willows trees (Salix exigua) were planted in near shore sediments as part of a phytoremediation treatability study. Disturbance of the site resulted in colonization by Phragmites australis, the common reed plant, and Typha latifolia, cattails. Sediment analyses in 2004 showed that PAH contamination for oiled-shore sediments was greatest in the first 5 inches of sediment (personal communication, Steve Rock, USEPA).

Sediment samples were collected by removing approximately $10 \mathrm{~cm}$ of sediment by hand trowel or shovel within a $2 \mathrm{~m}$ diameter of vegetated or non-vegetated sediments. Sediment samples were collected at 6 to 9 locations for each plant species and 3 locations of non-vegetated sediments. Non-vegetated sediments were composited at the site prior to storage and transport. In vegetated areas, plant litter and debris were removed from the sediment surface after which sediments with plants roots were removed in toto. Visible plant roots and plant material were removed from sediments prior to mixing sediments together for each plant species. Sediments were transported in plastic bags at $0^{\circ} \mathrm{C}$. Prior to 
chemical fractionation and analyses, small visual root residuals were removed, and sediments were sieved $(2 \mathrm{~mm})$ and homogenized again in ceramic bowls.

\subsection{Sediment Fractionation.}

Aliquots of bulk sediment (10-15 g.) were first freeze-dried and weighed to obtain sediment masses, then chemically fractionated to obtain bulk sediment, humin, and deashed humin fractions. Chemical fractionation proceeded as follows: First, sediments were weighed and lipid extracted with $20 \mathrm{~mL}$ of a 4:1 mixture of dichloromethane: acetone on a shaker table for 24 hours. Solvent was decanted and sediments were again extracted with $20 \mathrm{~mL}$ of a 4:1 mixture of dichloromethane: acetone for 24 hours. Solvent fractions were combined and this extract is referred to as the bulk sediment extract. Sediments were then extracted with a $0.1 \mathrm{~N}$ sodium hydroxide $(\mathrm{NaOH})$ solution for 24 hours, with the headspace of the tubes purged with $\mathrm{N}_{2}(\mathrm{~g})$. This treatment extracted the humic and fulvic acids from the sediment and destabilized the sediment matrix. $\mathrm{NaOH}$ was decanted from the sediments after 24 hours and sediments were lipid extracted with $20 \mathrm{~mL}$ of dichloromethane for 24 hours. Solvent was decanted and sediments were again extracted with $20 \mathrm{~mL}$ of dichloromethane for 24 hours. Solvent fractions were combined and this extract is referred to as the bulk humin or humin extract. Sediments were then extracted with a $10 \%$ solution of hydrogen fluoride: hydrochloric acid ( $\mathrm{HF}: \mathrm{HCl})$ solution for 7 days, with the headspace of the tubes purged with $\mathrm{N}_{2}(\mathrm{~g})$. This treatment dissolves the mineral matrix of the sediment and further destabilized the sediment matrix. The HF:HCl solution was decanted from the sediments after 24 hours and sediments were lipid extracted with $20 \mathrm{~mL}$ of dichloromethane for 24 hours. Solvent was decanted and sediments were again extracted 
with $20 \mathrm{~mL}$ of dichloromethane for 24 hours. Solvent fractions were combined and this extract is referred to as the HF humin or de-ashed humin extract. Preferential loss of larger alkylated PAH homologues due to the chemical fractionation procedure of sediment has been evaluated and discussed previously (Gregory et al., 2005). Because sediments also contain significant metal contamination (Sand Creek Consultants, Inc. 2002), conductivity measurements of Phragmites and non-vegetated bulk sediments were determined using extracts of sediment/water ratios (Rhoades, J.D., 1996) and a YSI Model 85 multi probe meter (Yellow Springs, OH).

\subsection{OM Composition.}

Replicate aliquots of bulk sediment, humin, and de-ashed humin fractions were analyzed for percent organic carbon (\% OC) using an SOP NC $2100 \mathrm{CHN}$ Analyzer (Thermo Electron S.p.A., Milan, Italy). Sediment samples were sent to The Lawrence Livermore National Laboratory (Livermore, CA) for standard radiocarbon dating analysis. Sediment fractions were combusted to $\mathrm{CO}_{2}$ then reacted with a $\mathrm{Fe} / \mathrm{H}_{2}$ catalyst to form graphite. Samples were analyzed by Accelerator Mass Spectrometry (AMS) with standards (NBS Oxalic Acid I and II (NIST-SRM-4990, 4990c) and blanks for organic carbon samples (Johnson-Mathey 99.9999\% graphite powder). Splits of combusted samples were taken for ${ }^{13} \mathrm{C}$ analysis to correct AMS values (Stuiever and Polach, 1997). Data is expressed as the percent modern carbon $\left({ }^{14} \mathrm{C}\right.$ PMC) determined from the measurement of fraction modern that is the deviation of the ${ }^{14} \mathrm{C} / \mathrm{C}$ ratio of a sample from "modern" (Stuiever and Polach). Petroleum contains very little ${ }^{14} \mathrm{C}$ activity $\left({ }^{14} \mathrm{C} \mathrm{PMC} \sim 0 \%\right)$ because of its 
ancient origin; whereas, modern plant carbon and recent humification of modern plant carbon will reflect modern ${ }^{14} \mathrm{C}$ activity $\left({ }^{14} \mathrm{C}\right.$ PMC 100\%) from atmospheric ${ }^{14} \mathrm{CO}_{2}$.

\subsection{Fourier Transform Infra-Red Specrtoscopy.}

Approximately $1 \mathrm{mg}$ of freeze dried, fractionated sediment was ground with approximately $0.1 \mathrm{~g}$ of Potassium Bromide $(\mathrm{KBr})$ and pressed into a pellet using a manual press. Spectra were then collected on a Nicolet Impact 400 FTIR (Nicolet, Madison, Wisconsin). Spectra were recorded by co-addition of 32 spectra with a resolution of $4 \mathrm{~cm}^{-1}$.

\subsection{Gas Chromatography/Mass Spectroscopy with Select Ion Monitoring.}

Extracts of bulk sediment, humin, and de-ashed humin were first loaded onto neutral activated alumina columns prior to analysis by Gas Chromatography/Mass Spectroscopy (GC/MS). Extracts were concentrated to $5 \mathrm{~mL}$, split for archival purposes, and then spiked with deuterated phenanthrene $\left(d_{10}, 500 \mathrm{ng} / \mathrm{mL}\right)$ and benzo[a]pyrene $\left(d_{8}, 505 \mathrm{ng} / \mathrm{mL}\right)$ as internal standards. Extracts were analyzed for 42 PAHs using a modified method of EPA 8270 EPA 8270 (US EPA, 1986b) similar to that employed by Luellen and Shea (2002).

GC/MS select ion monitoring (SIM) mode analyses were conducted on a HP5890 Series II GC equipped with electronic pressure control connected to an Agilent 6890 using a Restek $30 \mathrm{~m} \times 0.25 \mathrm{~mm}$ Rtx-5 (film thickness $0.25 \mathrm{\mu m}$ ) MS w/Integra-Guard column. PAH homologues that were quantified using this method are listed in Table 1. 


\subsection{Statistical Analyses.}

Statistical significance was determined by Dunnett's ANOVA $(p<0.05)$ (Dunnet, $1955,1964)$ by which multiple means of vegetated data sets were compared against nonvegetated controls. Student t-tests were also performed to determine statistical significance between different vegetated sites. Unless otherwise noted, triplicate samples were used to determine the averaged recoveries of PAHs in sediment extracts and total organic carbon present in sediment samples. Values in tables represent the mean of measurements \pm one standard deviation. 
Table 1. Inventory of 42 Alkylated and Non-alkylated PAHs

\begin{tabular}{|c|c|c|c|c|c|}
\hline analyte & abbrev & no. of rings & analyte & abbrev & no. of rings \\
\hline naphthalene ${ }^{a}$ & No & 2 & fluoranthene $\mathrm{e}^{a}$ & FL & 4 \\
\hline biphenyl & BP & 2 & pyrene $^{a}$ & PY & 4 \\
\hline acenaphthylene $^{a}$ & ACL & 3 & C1-fluoranthenes/pyrenes & FP1 & 4 \\
\hline acenaphthelene $^{a}$ & $\mathrm{ACE}$ & 3 & retene & $\operatorname{Re}$ & 4 \\
\hline dibenzofuran & Dfu & 3 & benz $[a]$ anthracene $e^{a}$ & $\mathrm{BaA}$ & 4 \\
\hline C1-naphthalenes & N1 & 2 & chrysene $^{a}$ & $\mathrm{C} 0$ & 4 \\
\hline C2-naphthalenes & $\mathrm{N} 2$ & 2 & C1-chrysenes & $\mathrm{C} 1$ & 4 \\
\hline C3-naphthalenes & N3 & 2 & C2-chrysenes & $\mathrm{C} 2$ & 4 \\
\hline C4-naphthalenes & N4 & 2 & C3-chrysenes & $\mathrm{C} 3$ & 4 \\
\hline fluorene $^{a}$ & F0 & 3 & C4-chrysenes & $\mathrm{C} 4$ & 4 \\
\hline C1-fluorenes & $\mathrm{F} 1$ & 3 & benzo $[b]$ fluoranthene ${ }^{a}$ & $\mathrm{BbF}$ & 5 \\
\hline C2-fluorenes & $\mathrm{F} 2$ & 3 & benzo[k]fluoranthene ${ }^{a}$ & $\mathrm{BkF}$ & 5 \\
\hline C3-fluorenes & F3 & 3 & benzo $[e]$ pyrene & $\mathrm{BeP}$ & 5 \\
\hline dibenzothiophene & D0 & 3 & benzo $[a]$ pyrene ${ }^{a}$ & $\mathrm{BaP}$ & 5 \\
\hline C1-dibenzothiophene & D1 & 3 & perylene & Pryl & 5 \\
\hline C2-dibenzothiophene & D2 & 3 & indeno $[1,2,3-c d]$ pyrene ${ }^{a}$ & IOP & 6 \\
\hline C3-dibenzothiophene & D3 & 3 & $\operatorname{dibenz}[a, h]$ anthracene $^{a}$ & DA & 5 \\
\hline anthracene ${ }^{a}$ & AN & 3 & benzo $[g, h, i]$ perylene ${ }^{a}$ & $\mathrm{BgP}$ & 6 \\
\hline phenanthrene $^{a}$ & P0 & 3 & coronene & Co & 6 \\
\hline C1-phenanthrenes/anthracenes & $\mathrm{P} 1$ & 3 & & & \\
\hline C2-phenanthrenes/anthracenes & $\mathrm{P} 2$ & 3 & & & \\
\hline C3-phenanthrenes/anthracenes & $\mathrm{P} 3$ & 3 & & & \\
\hline C4-phenanthrenes/anthracenes & $\mathrm{P} 4$ & 3 & & & \\
\hline
\end{tabular}




\section{CHAPTER 3. RESULTS}

The original composite samples are referred to as bulk sediment fractions. Humin represents the sediment organic matrix after extraction with dichloromethane (DCM) and alkaline salts to remove lipids and humic/fulvic acids, respectively. De-ashed humin represents humin after extraction with $\mathrm{HF} / \mathrm{HCl}$ to remove the mineral matrix.

\subsection{Impact of Vegetation on Sediment Composition.}

Data from FTIR (Figure 1.) show very little difference in the bulk sediment between vegetated and non-vegetated samples. Both vegetated and non vegetated samples show stretching in the $3000-2700 \mathrm{~cm}^{-1}$ region. This region is characterized as stretching of methyl and methylene groups, indicating alkane content (Michalian, K.H. and Freisen, W.I. 1990; Painter, P.C. et al, 1981; Silverstein, R.M. et al, 1991; Ledesma, E.B. et al. 2000). As expected, moving into bulk humin that has been lipid extracted, these peaks disappear. All sediments also show the characteristic mixture of peaks in the $900-650 \mathrm{~cm}^{-1}$ region indicating polycyclic aromatic compounds are still present in the sediment fractions. In bulk sediments, there appears to be less of a contribution due to $\mathrm{C}-\mathrm{H}$ stretching and bending

in the vegetated zone as evidenced by peaks near 2900 and $1400 \mathrm{~cm}^{-1}$ respectively and slightly more contribution from the more polar C-O stretch at $1000 \mathrm{~cm}^{-1}$ (Silverstein, R.M. et al, 1991), but the high levels of petroleum contamination mask any major shifts. This is not the case in the bulk humin where much of the available petroleum residue has been lipid extracted from the sediment. The effects of vegetation are much more obvious in the bulk humin. A significantly larger peak encompassing the C-O stretching zone around 1100 
$\mathrm{cm}^{-1}$ is present in vegetated sediments vs. the non-vegetated control. The effects of vegetation on total organic carbon (TOC) are visible in figure 2, with little deviation between sites.

\subsection{PAH Concentrations in Sediment Fractions.}

Individual PAH concentration data for Bulk Sediment, Humin, and De-ashed humin can be seen in tables 2-4. Mean concentrations of 42 alkylated and non-alkylated PAHs [TPAH] and the sum of the 16 EPA priority PAHs do not significantly decline between non-vegetated and vegetated bulk sediments (Table 5.) (Dunnett's ANOVA, $p<0.05$ ). Humin and de-ashed humin fractions also showed no significant declines in TPAH concentrations between non-vegetated and vegetated sediment fractions (Table 6) (Dunnett's ANOVA, $p<0.05$ ). In fact, TPAH concentrations for Phragmites and cattails humin fractions increased relative to non-vegetated humin fractions.

Humin fractions of cattails had significantly greater TPAH concentrations than the other humin fractions analyzed (t-test, $p<0.05$ ), and Phragmites de-ashed humin had greater, though not significantly greater, TPAH concentrations than all other de-ashed humin fractions $(t$-test, $p<0.05)$. These findings could be attributed to site heterogeneity and variant PAH concentration distributions. However, Rockne et al., 2002 observed that $85 \%$ of TPAHs in an estuarine sediment were found in sediment fractions that contained plant detrital material even though these fractions only contained $4 \%$ of the total sediment mass. Thus, the presence of Phragmites or cattail plant material in humin fractions may explain increased TPAH concentrations in these fractions. 
In order to account for lower PAH recovery due to carbon dilution from plant carbon inputs, TPAH concentrations were carbon-normalized in each sediment fraction (Table 5). Carbon-normalized [TPAH] significantly decreased in all vegetated bulk sediments relative to non-vegetated bulk sediments (Dunnett's ANOVA, $p<0.05$; Table 6). However, carbon-normalized [TPAH] for humin and de-ashed humin fractions diverged from non-normalized TPAH data. Specifically, carbon-normalized [TPAH] for Phragmites and cattails humin were much greater than non-vegetated and willow tree humin. Also, Phragmites and willow tree de-ashed humin fractions had much greater carbon-normalized [TPAH] than cattails and non-vegetated de-ashed humin fractions.

\subsection{PAH Weathering and Sediment Composition.}

Weathering is a phenomenon by which the chemical composition of PAH contamination changes and dissipates over time. In general, more alkylated homologues are more stable and resistant to degradation. Examples of weathered vs. unweathered PAH distributions can be seen in PAH histograms of the 4 study sites shown in figures 3-6. Unweathered alkylated PAH distributions are seen in figure 3 (non vegetated sediment). More weathered distributions are present in figure 4 (Phragmites colonized sediment). Weathering patterns are useful only qualitatively. Alkylated $\mathrm{PAH}$ ratios provide a quantitative measure of PAH weathering and can be used (1) to describe the degree of weathering and biodegradation of spilled oil and (2) to predict and monitor the effectiveness of remediation activities (Douglas et al., 1996). The ratio of $\mathrm{C}_{3}$-naphthalenes and $\mathrm{C}_{2}$-phenanthrenes $\left(\mathrm{N}_{3} / \mathrm{P}_{2}\right)$ is used for diesel fuel and crude oil in the early stages of 
weathering as the tri-alkylated napthalenes have a shorter lifespan in relation to many other PAHs. $\mathrm{C}_{3}$-dibenzothiophenes vs. $\mathrm{C}_{3}$-chrysenes $\left(\mathrm{D}_{3} / \mathrm{C}_{3}\right)$ ratios can be used to detect later stages of weathering for diesel and crude oils (Douglas et al., 1996). We did not observe more weathered $\mathrm{D} 3 / \mathrm{C} 3$ ratios for any vegetated sediment fractions relative to the nonvegetated sediment fractions. This outcome is not unexpected given the short exposure of sediment to vegetation (2 years).

Figure 7 shows cross plots of $\mathrm{N}_{3} / \mathrm{P}_{2}$ weathering ratios to percent total organic carbon (\%TOC) for all sediment fractions. More weathered ratios are observed for Phragmites bulk sediment and humin fractions and willow tree humin relative to non-vegetated fractions. $\mathrm{N}_{3} / \mathrm{P}_{2}$ ratios for all samples in de-ashed humin were similar; this is not unexpected given the refractory nature of de-ashed humin and the short period of exposure to vegetation. Relationships between $\%$ TOC and $\mathrm{N}_{3} / \mathrm{P}_{2}$ ratios for non-vegetated and Phragmites bulk sediment and humin fractions are not apparent. In fact, there is no consistent pattern between $\mathrm{N}_{3} / \mathrm{P}_{2}$ ratios and sediment fractions for either non-vegetated or vegetated sites. Previously, we observed increased $\mathrm{N}_{3} / \mathrm{P}_{2}$ weathering with increased \% TOC in distillate refinery waste colonized by Phragmites and other trees and shrubs after 30 years of plant growth (Gregory et al., 2005). This trend is not evident in these sediments after only two years of vegetative growth. Organic carbon content of sediment fractions does not appear related to PAH dissipation nor even to the presence of vegetation.

Figure 8 shows a more consistent relationship between $\mathrm{N}_{3} / \mathrm{P}_{2}$ weathering ratios and percent modern carbon (PMC) measurements. For bulk sediment and humin fractions, the most weathered ratios are observed in Phragmites fractions that contain more ${ }^{14} \mathrm{C}$ activity, or modern carbon, than all other sediment fractions (Figure 8). Willow trees also had more 
weathered $\mathrm{N}_{3} / \mathrm{P}_{2}$ ratios in humin fractions and more modern carbon than non-vegetated humin. All three vegetated de-ashed humin fractions were more weathered than nonvegetated de-ashed humin but only cattails and Phragmites contained more modern carbon than non-vegetated de-ashed humin.

\subsection{Phragmites' ability to colonize contaminated sediment}

Visual differences between plant colonization of Indiana Harbor Canal (IHC) sediments are presented in Figure 4 (photos courtesy of Steve Rock). IHC sediments were planted with either cattails or Phragmites that had been harvested from the IHC site during sediment collection. Plants were rooted in clean soil on top of IHC sediment; the two sediments (clean and IHC) were separated by burlap material. As is evident in Figure 9, Phragmites roots grew around the burlap material and into the IHC sediment. Cattails roots did not penetrate IHC sediment and remained in the clean soil. Such distinct differences may readily explain the observed differences in plant carbon accumulation and PAH weathering between Phragmites and cattail sediment fractions in our study. 


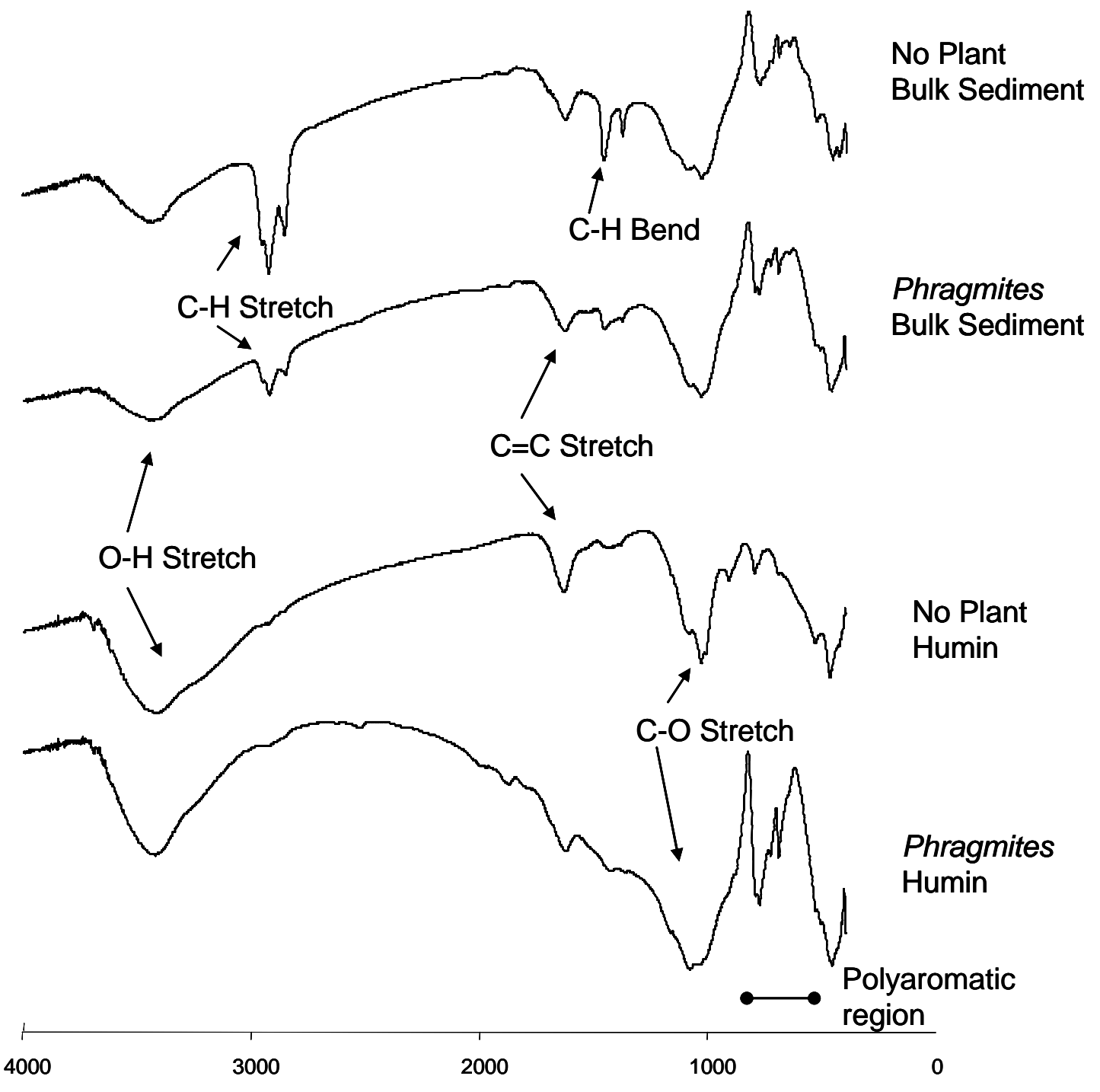

Figure 1. Selected Fourier Transform Infrared (FTIR) spectra of Indiana Harbor Sediment Fractions. 

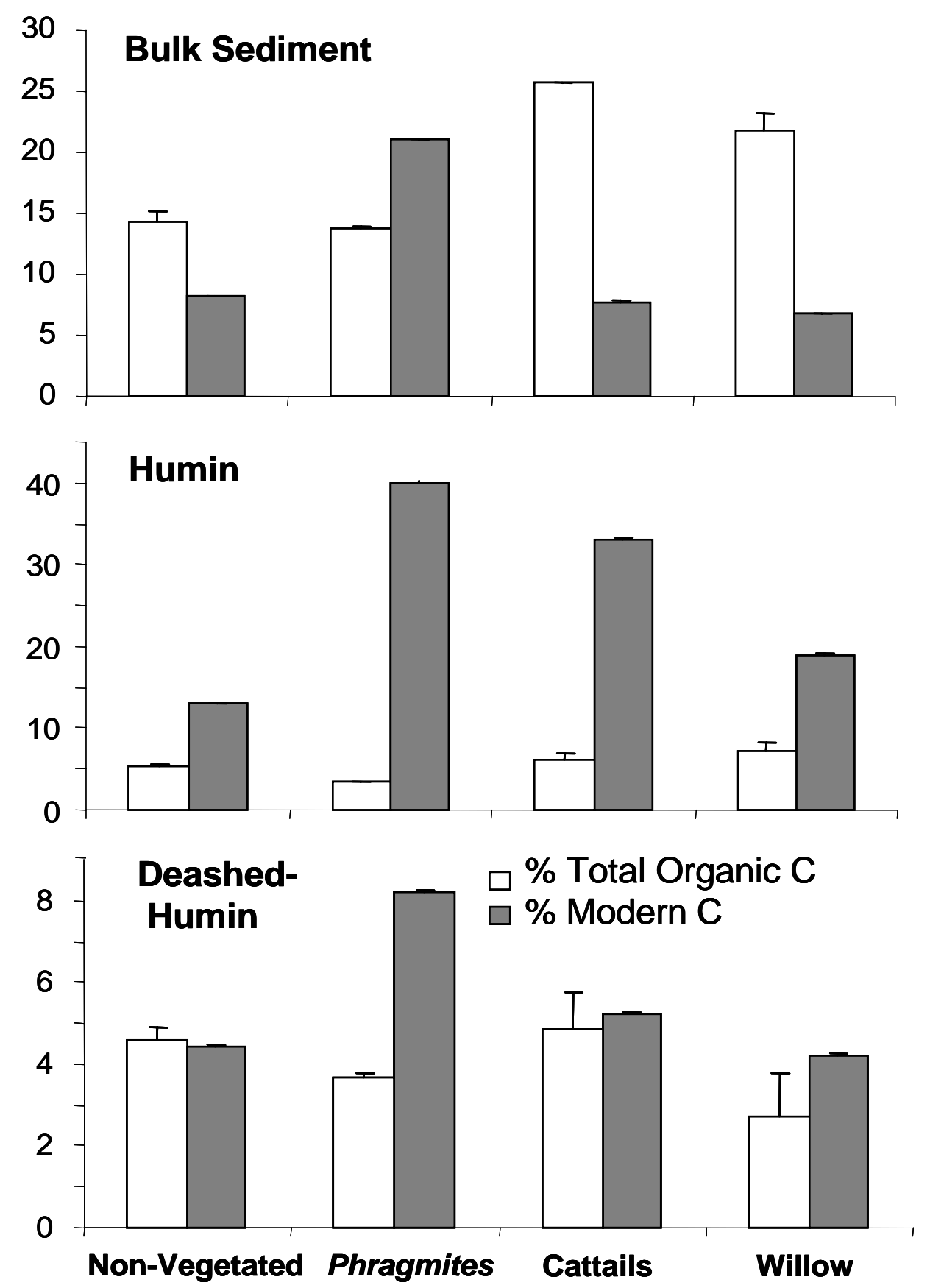

Figure 2. Total Organic Carbon (\% TOC) and Percent Modern Carbon (\% PMC) for bulk sediment and humin fractions of vegetated and non vegetated sediments at the Indiana Harbor Canal site. Values are means \pm one standard deviation. 


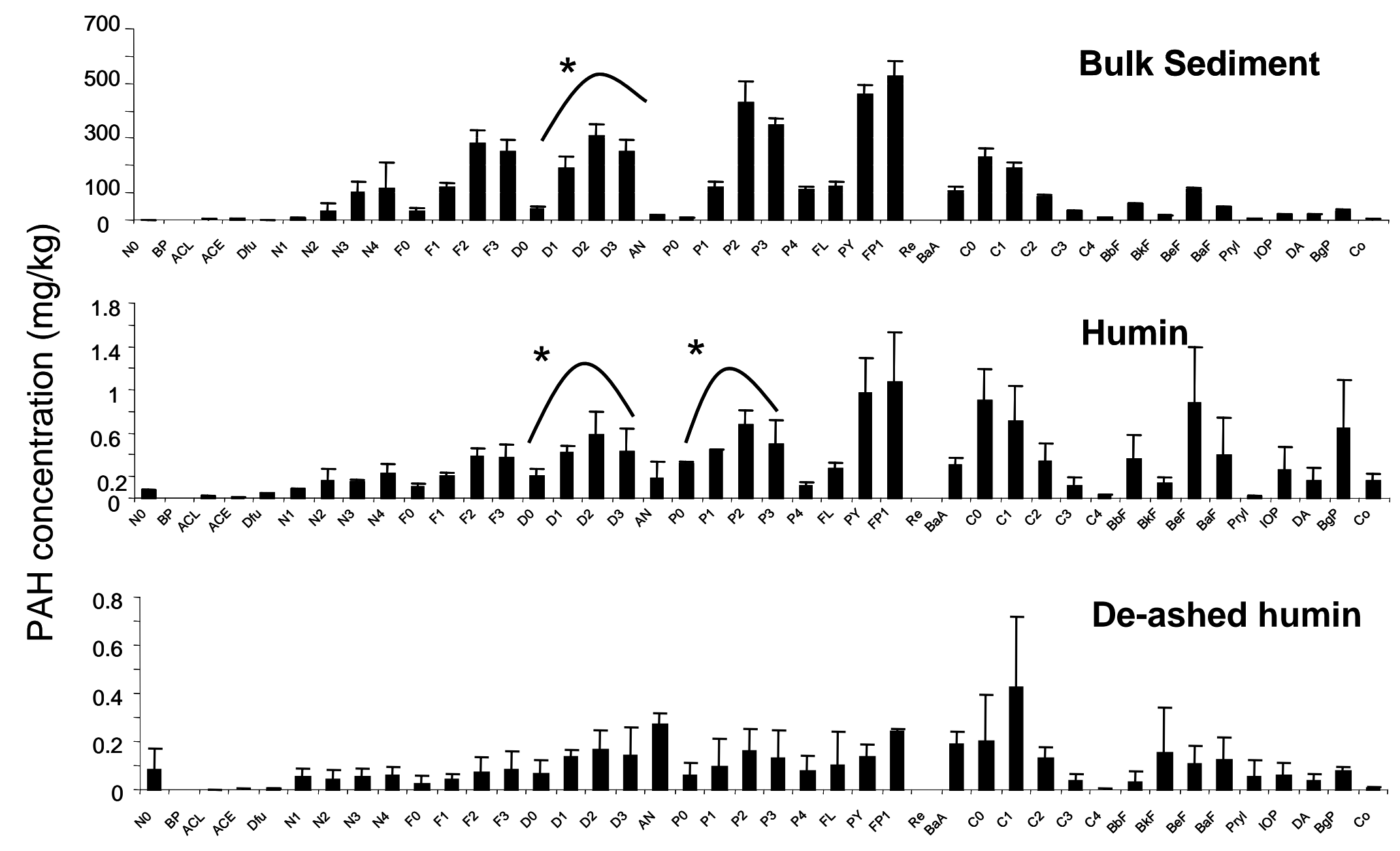

Figure 3. Individual PAH concentrations from the non vegetated zone from bulk sediment, humin, and de-ashed humin. Error bars indicate one standard deviation with $n=3$. * indicated a non weathered alkylated PAH distribution. 


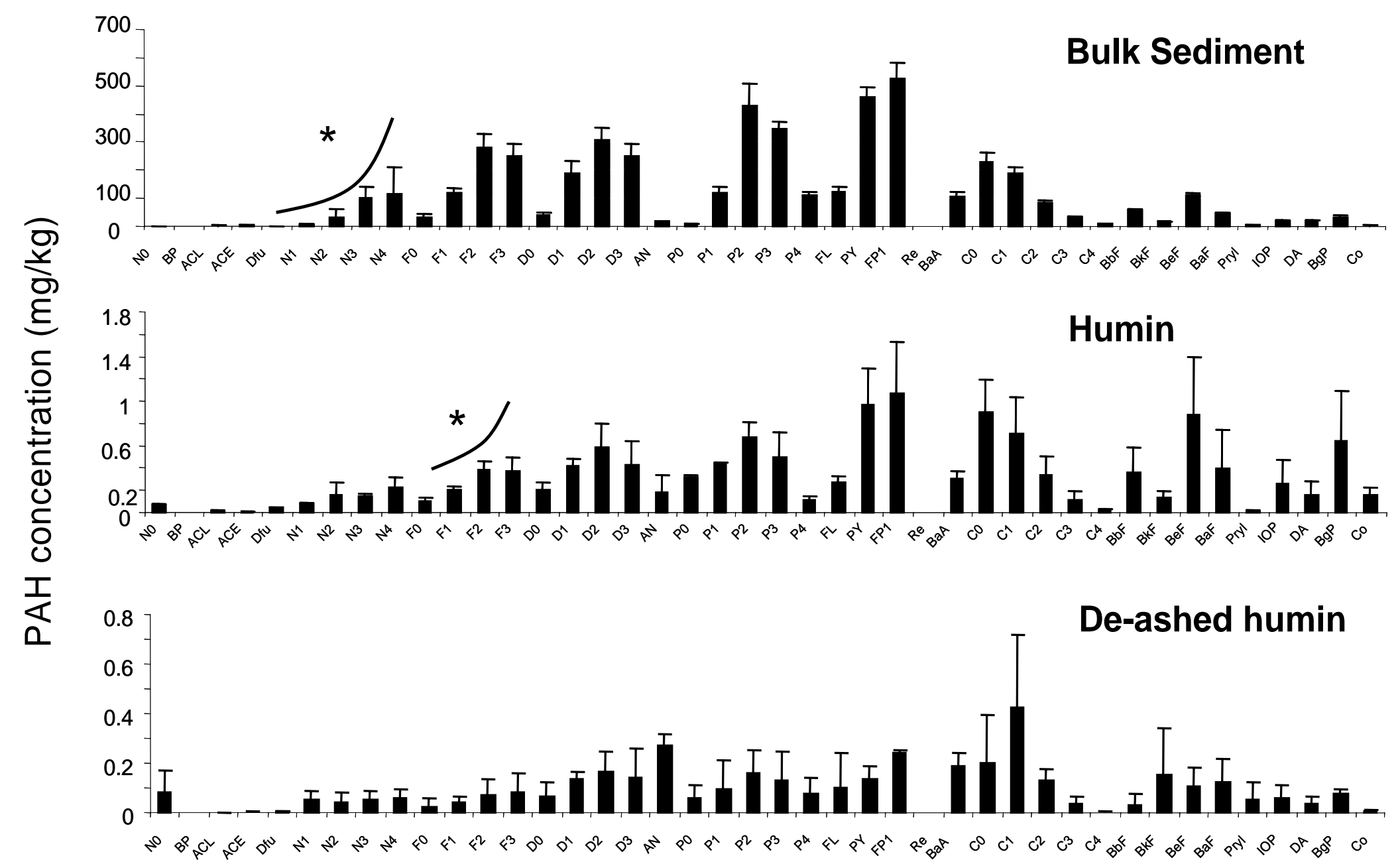

Figure 4. Individual PAH concentrations from the Phragmites dominated zone from bulk sediment, humin, and de-ashed humin. Error bars indicate one standard deviation with $n=3$. * indicated a weathered alkylated PAH distribution. 


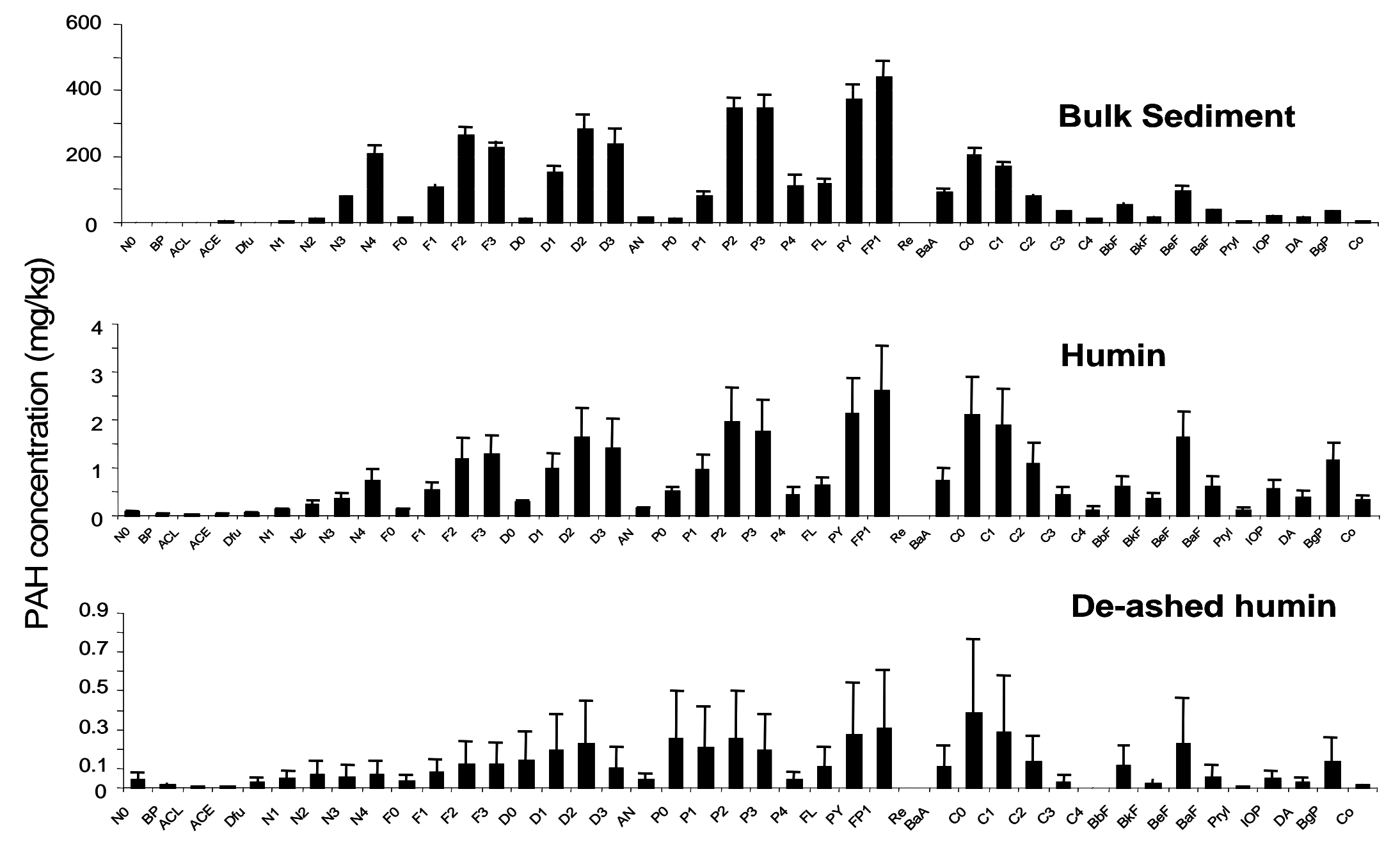

Figure 5. Individual PAH concentrations from the Cattails dominated zone from bulk sediment, humin, and de-ashed humin. Error bars indicate one standard deviation with $\mathrm{n}=3$. 


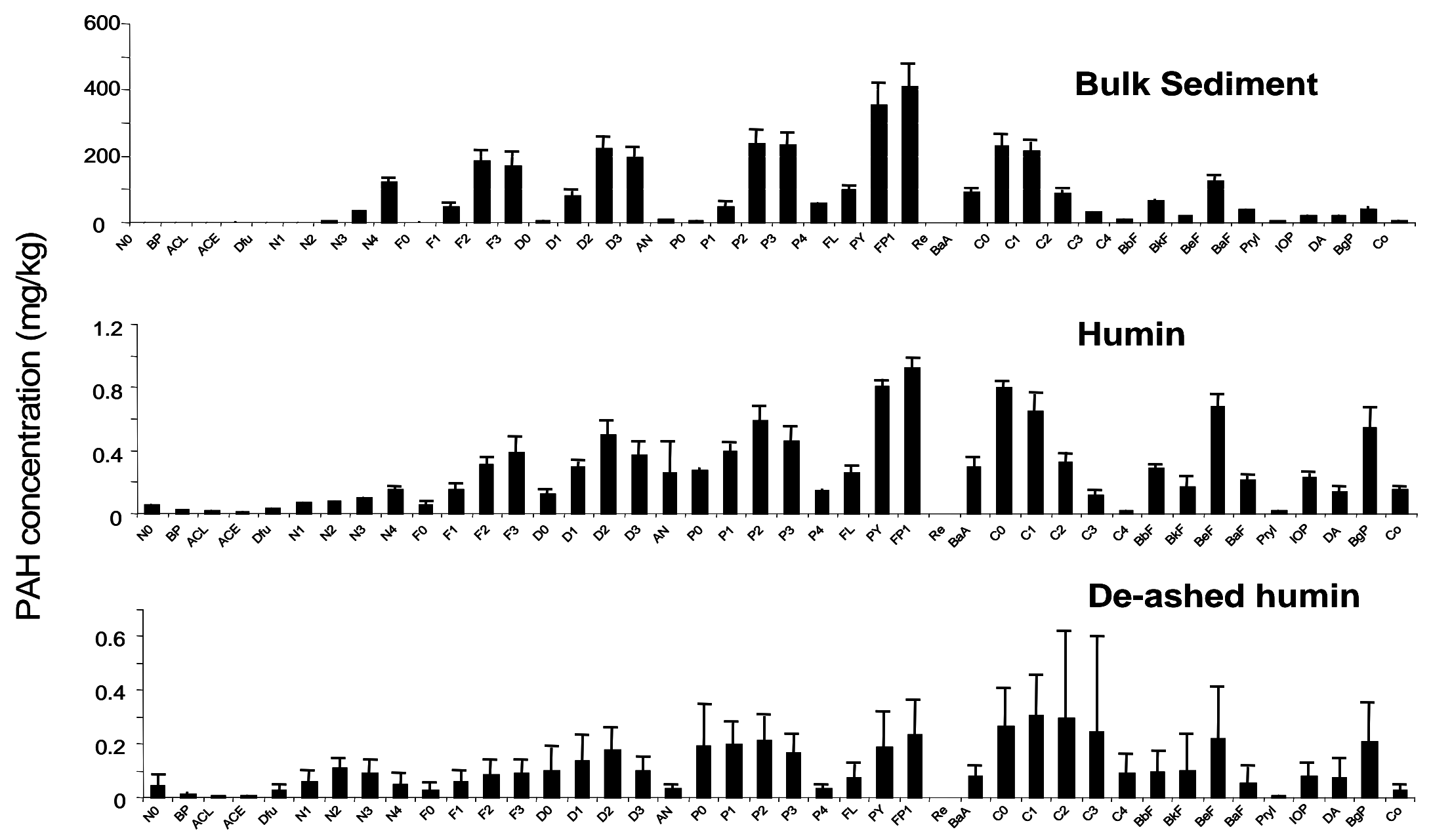

Figure 6. Individual PAH concentrations from the Willow dominated zone from bulk sediment, humin, and de-ashed humin. Error bars indicate one standard deviation with $\mathrm{n}=3$. 

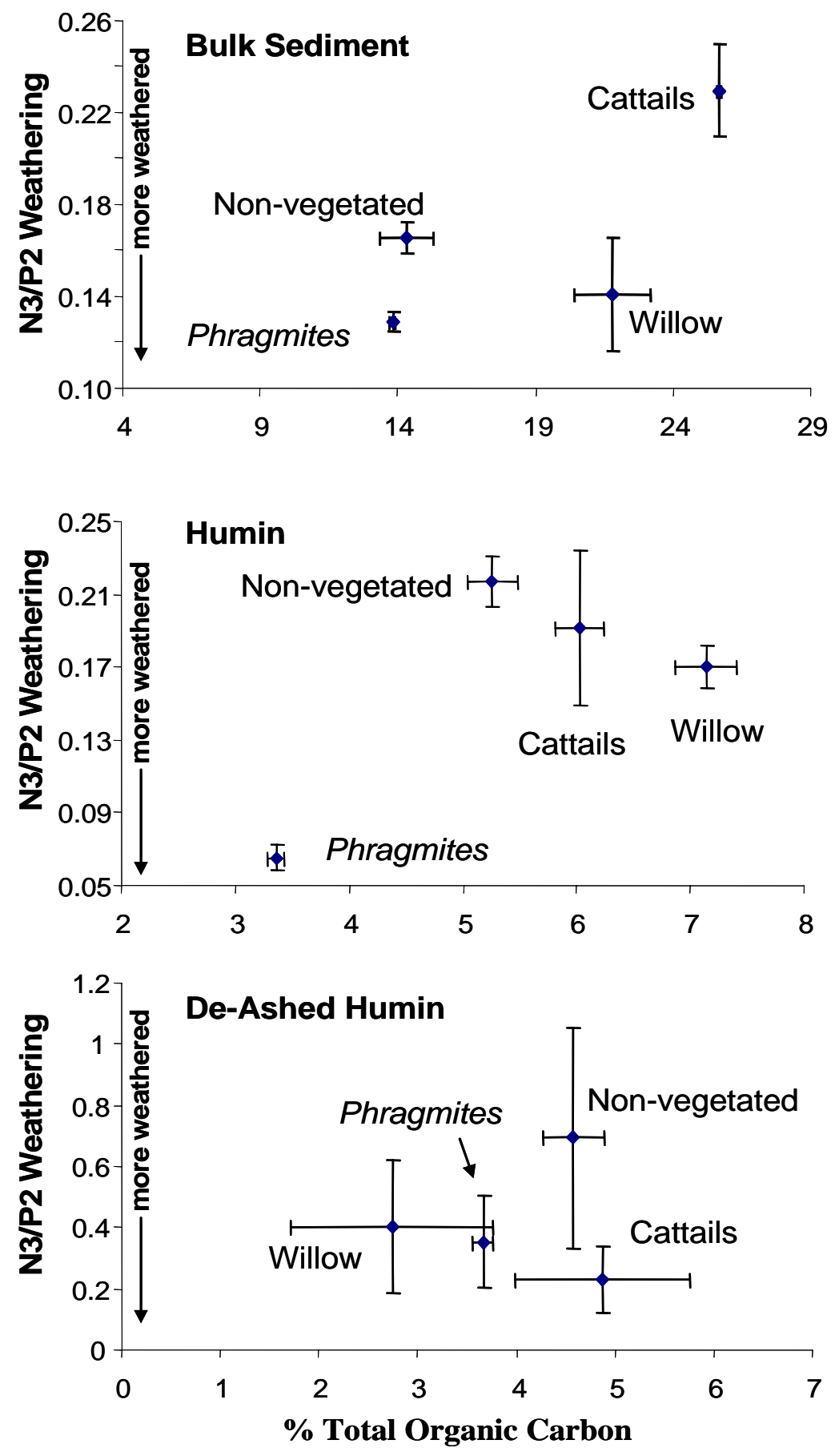

Figure 7. Cross plots of $\mathrm{C}_{3}$-naphthalenes to $\mathrm{C}_{2}$-phenanthrenes $\left(\mathrm{N}_{3} / \mathrm{P}_{2}\right)$ alkylated PAH homologues to percent Total Organic Carbon (\% TOC) for sediment and humin fractions of vegetated and non vegetated sediments at the Indiana Harbor Canal site. Values are means \pm one standard deviation. 

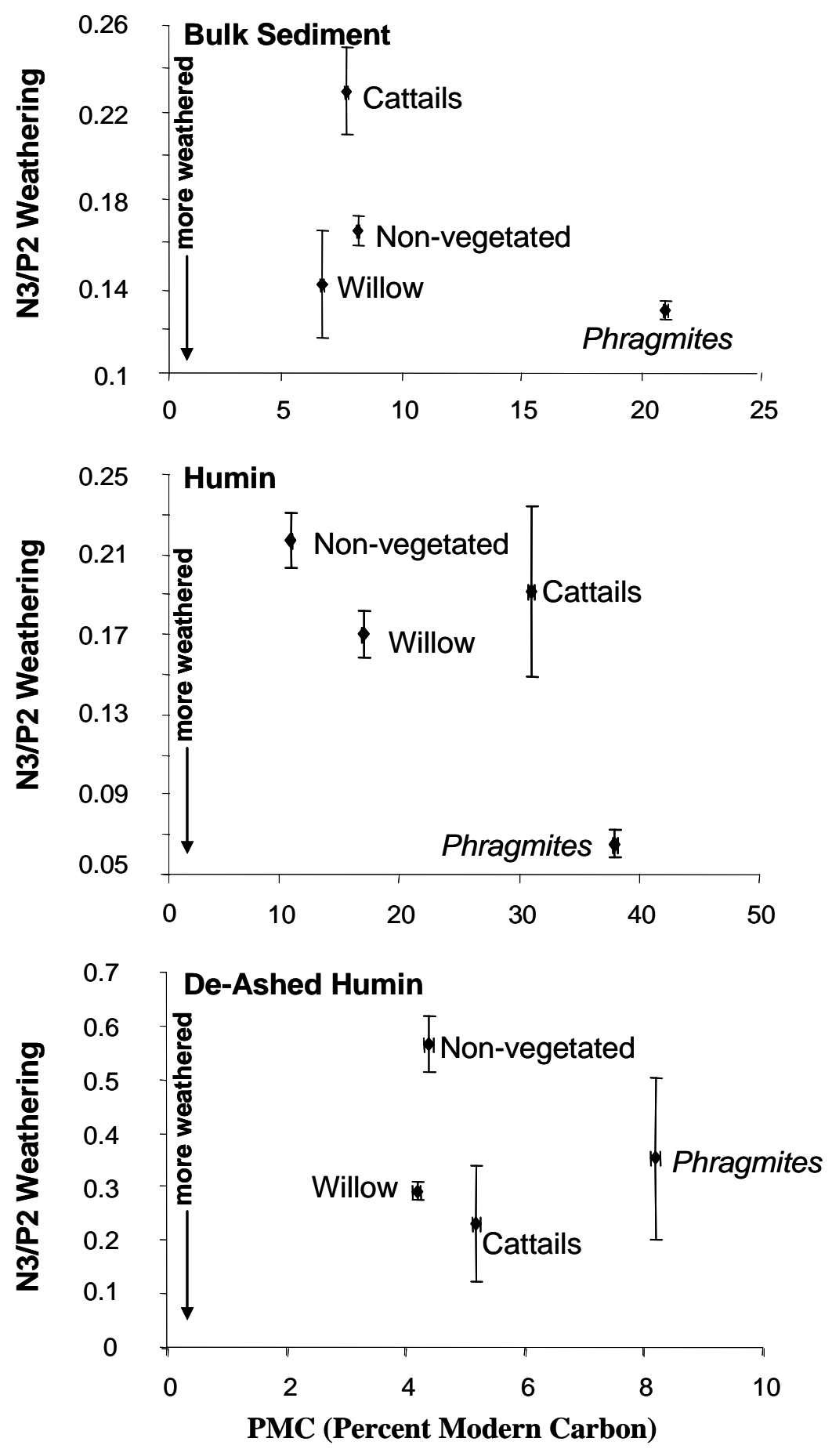

Figure 8. Cross plots of $\mathrm{C}_{3}$-naphthalenes to $\mathrm{C}_{2}$-phenanthrenes $\left(\mathrm{N}_{3} / \mathrm{P}_{2}\right)$ alkylated PAH homologues to. Percent Modern Carbon (PMC) for sediment and humin fractions of vegetated and non vegetated sediments at the Indiana Harbor Canal. Values are means \pm one standard deviation 


\section{Phragmites}
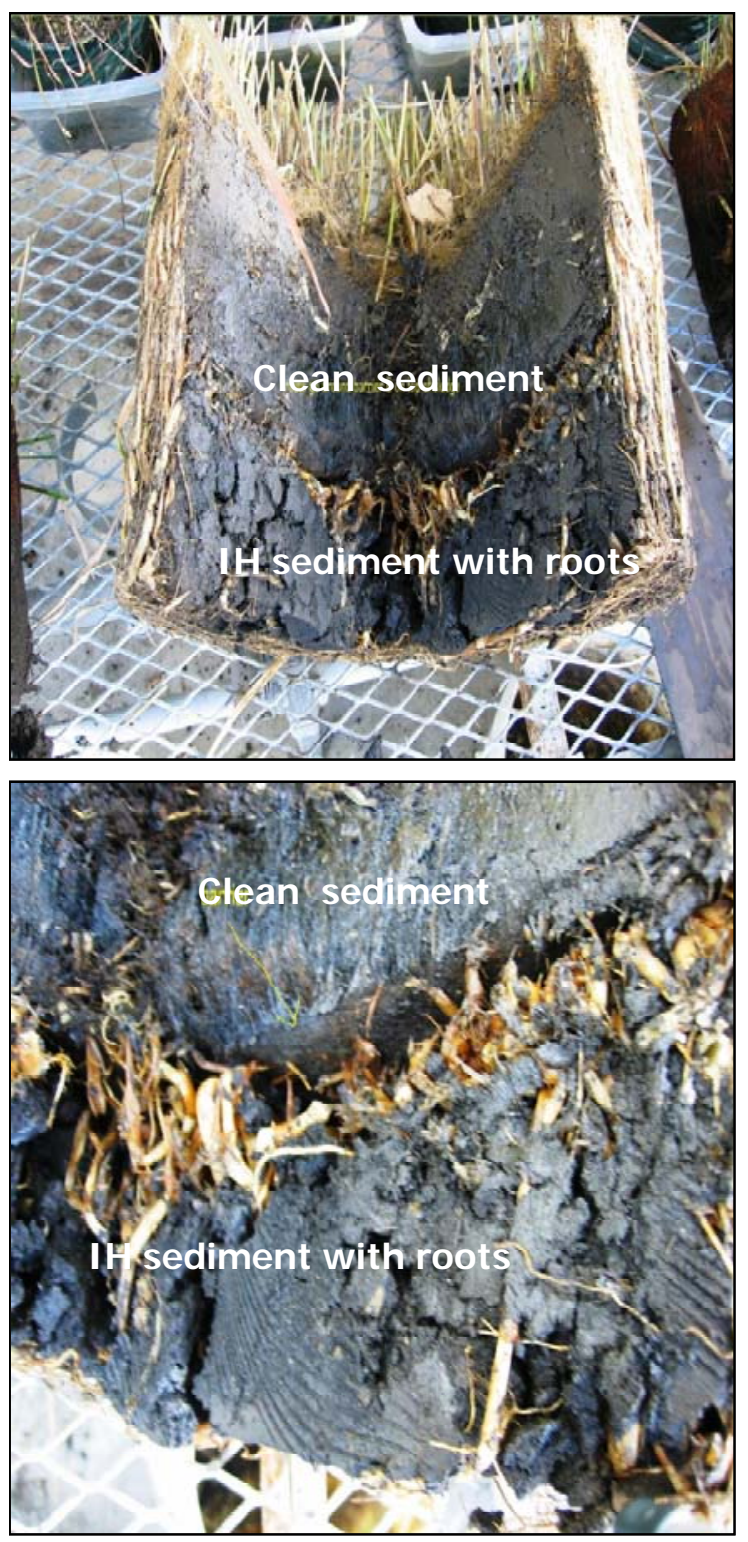

Courtesy of Steve Rock, USEPA
Cattails
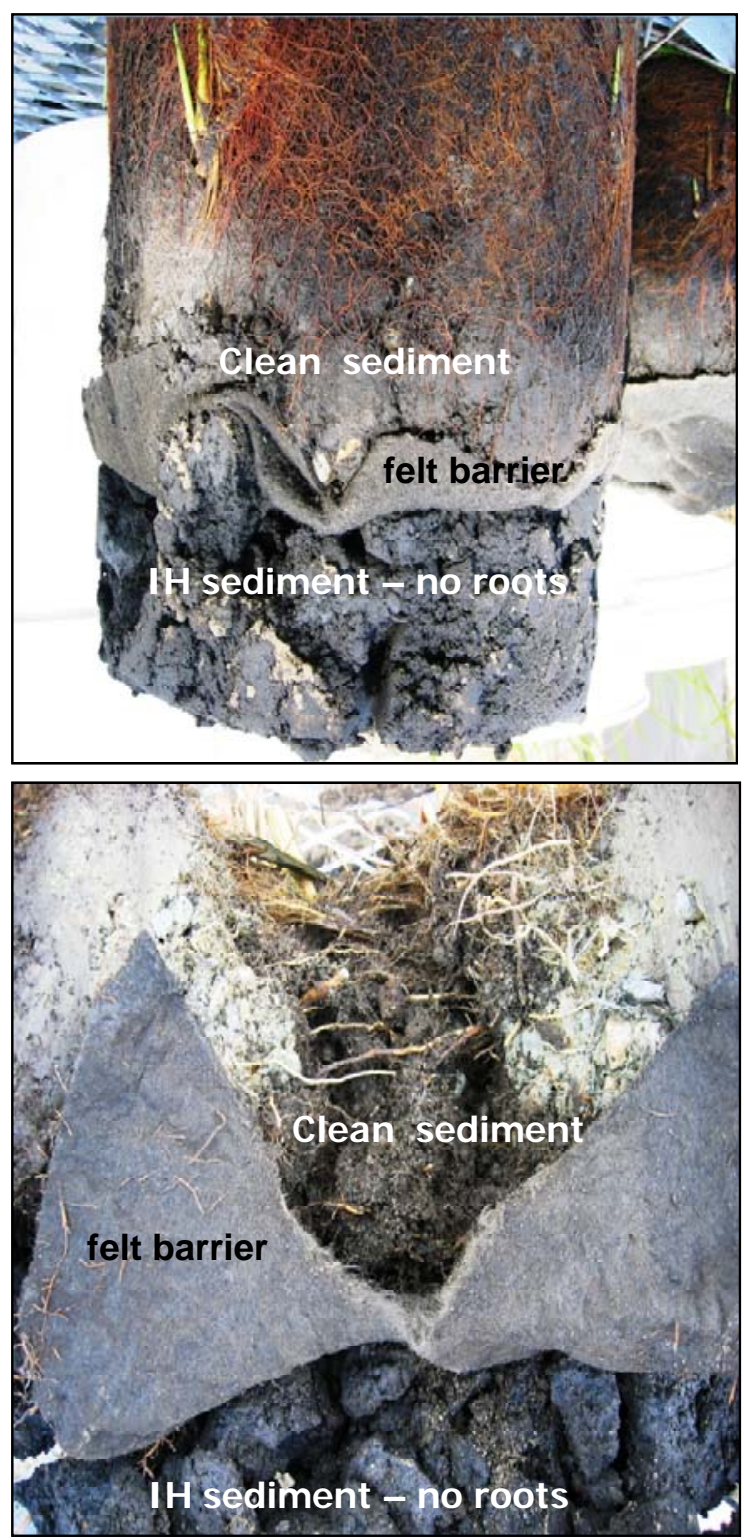

Figure 9. Phragmites australis and cattails (Typha angustifolia) growth in greenhouse containers. Plants were rooted in clean soil that was placed on top of Indiana Harbor Canal sediment. Phragmites grew around and into the oiled sediment, where as cattails did not. 
Table 2. PAH concentrations for parent compounds and alkylated homologues from

Bulk Sedment extracts. Concentrations are given in $\mu \mathrm{g} / \mathrm{g}$ sediment with $\mathrm{n}=3$.

\begin{tabular}{|c|c|c|c|c|c|c|c|c|c|}
\hline & & \multicolumn{2}{|c|}{ Non-Vegetated } & \multicolumn{2}{|c|}{ Phragmites australis } & \multicolumn{2}{|c|}{ Cattails } & \multicolumn{2}{|c|}{ Willow } \\
\hline & & Ave & $\begin{array}{l}\text { Std } \\
\text { dev }\end{array}$ & Ave & Std dev & Ave & Std dev & Ave & Std dev \\
\hline Naphthalene & No & 0.67 & 0.05 & 1.08 & 0.24 & 1.14 & 0.34 & 0.59 & 0.11 \\
\hline Biphenyl & $\mathrm{BP}$ & & & 0.29 & 0.02 & 0.34 & 0.15 & 0.15 & 0.03 \\
\hline Acenaphthylene & ACL & 1.63 & 1.29 & 0.96 & 0.13 & 1.81 & 0.46 & 1.37 & 0.24 \\
\hline Acenaphthene & $\mathrm{ACE}$ & 2.87 & 1.66 & 1.41 & 0.20 & 6.68 & 1.15 & 1.82 & 0.29 \\
\hline Dibenzofuran & Dfu & 1.27 & 0.51 & 0.88 & 0.06 & 1.21 & 0.30 & 0.65 & 0.06 \\
\hline C1 - Naphthalenes & N1 & 4.26 & 4.46 & 1.73 & 0.25 & 3.28 & 1.02 & 1.32 & 0.17 \\
\hline C2 - Naphthalenes & $\mathrm{N} 2$ & 30.67 & 29.47 & 5.14 & 0.48 & 17.27 & 2.51 & 4.33 & 0.34 \\
\hline C3 - Naphthalenes & N3 & 100.60 & 39.32 & 50.28 & 2.90 & 105.21 & 6.54 & 32.74 & 4.87 \\
\hline C4 - Naphthalenes & N4 & 112.57 & 98.50 & 105.64 & 5.98 & 272.81 & 38.87 & 119.82 & 10.23 \\
\hline Fluorene & Fo & 31.82 & 13.43 & 6.39 & 0.21 & 18.56 & 2.29 & 0.88 & 1.03 \\
\hline C1 - Fluorenes & F1 & 116.53 & 18.78 & 58.69 & 2.65 & 140.60 & 15.27 & 46.72 & 9.27 \\
\hline C2 - Fluorenes & F2 & 282.06 & 45.92 & 199.71 & 11.26 & 349.69 & 34.37 & 182.50 & 33.64 \\
\hline C3 - Fluorenes & F3 & 250.75 & 41.40 & 153.21 & 8.67 & 297.89 & 30.30 & 169.80 & 42.06 \\
\hline Dibenzothiophene & Do & 38.23 & 11.15 & 31.50 & 1.77 & 15.90 & 3.96 & 4.95 & 0.97 \\
\hline C1 - Dibenzothiophene & D1 & 189.09 & 42.11 & 137.61 & 8.43 & 201.80 & 27.27 & 76.99 & 15.38 \\
\hline C2 - Dibenzothiophene & D2 & 307.07 & 42.08 & 243.31 & 13.29 & 376.09 & 55.29 & 219.82 & 42.92 \\
\hline C3 - Dibenzothiophene & D3 & 250.99 & 40.96 & 181.84 & 13.89 & 313.46 & 62.16 & 196.61 & 29.85 \\
\hline Anthracene & AN & 15.34 & 3.12 & 7.53 & 0.42 & 17.90 & 2.59 & 6.26 & 1.49 \\
\hline Phenanthrene & Po & 8.19 & 0.51 & 7.22 & 0.58 & 14.18 & 4.81 & 5.45 & 0.52 \\
\hline C1 - Phenanthrenes/Anthracenes & P1 & 118.33 & 21.84 & 105.39 & 7.92 & 105.29 & 13.24 & 46.81 & 12.26 \\
\hline
\end{tabular}


Table 2 continued

$\begin{array}{cccc}\text { Non-Vegetated } & \begin{array}{c}\text { Phragmites } \\ \text { australis }\end{array} \text { Cattails } & \text { Willow }\end{array}$

\begin{tabular}{|c|c|c|c|c|c|c|c|c|c|}
\hline & & Ave & $\begin{array}{l}\text { Std } \\
\text { dev }\end{array}$ & Ave & $\begin{array}{l}\text { Std } \\
\text { dev }\end{array}$ & Ave & $\begin{array}{l}\text { Std } \\
\text { dev }\end{array}$ & Ave & $\begin{array}{l}\text { Std } \\
\text { dev }\end{array}$ \\
\hline C2 - Phenanthrenes/Anthracenes & P2 & 429.90 & 75.42 & 390.22 & 17.15 & 460.10 & 41.10 & 235.08 & 42.14 \\
\hline C3 - Phenanthrenes/Anthracenes & P3 & 346.34 & 27.17 & 229.30 & 19.07 & 461.22 & 59.75 & 233.62 & 36.58 \\
\hline C4 - Phenanthrenes/Anthracenes & P4 & 109.61 & 11.86 & 43.41 & 4.03 & 142.99 & 51.97 & 55.53 & 5.16 \\
\hline Fluoranthene & FL & 124.42 & 16.86 & 104.34 & 3.04 & 152.87 & 21.81 & 95.63 & 18.37 \\
\hline Pyrene & PY & 457.20 & 36.74 & 361.30 & 23.56 & 494.21 & 60.67 & 352.72 & 69.12 \\
\hline C1 - Fluoranthenes/Pyrenes & FP1 & 524.47 & 56.63 & 439.06 & 18.10 & 582.64 & 66.09 & 409.91 & 73.47 \\
\hline Retene & $\operatorname{Re}$ & & & & & & & & \\
\hline Benz[a]anthracene & $\mathrm{BaA}$ & 104.90 & 17.19 & 101.39 & 6.75 & 120.48 & 14.51 & 90.25 & 14.45 \\
\hline Chrysene & $\mathrm{Co}$ & 229.13 & 33.91 & 205.49 & 15.71 & 270.21 & 25.57 & 229.98 & 37.69 \\
\hline C1 - Chrysenes & $\mathrm{C} 1$ & 188.29 & 20.02 & 173.30 & 14.32 & 226.73 & 11.81 & 213.68 & 28.99 \\
\hline C2 - Chrysenes & $\mathrm{C} 2$ & 83.56 & 6.42 & 67.44 & 5.07 & 106.64 & 7.58 & 85.71 & 10.23 \\
\hline C3 - Chrysenes & $\mathrm{C} 3$ & 31.21 & 3.31 & 22.98 & 2.25 & 45.71 & 5.16 & 31.27 & 3.06 \\
\hline C4 - Chrysenes & $\mathrm{C} 4$ & 6.64 & 1.12 & 5.25 & 0.82 & 14.21 & 2.63 & 8.31 & 2.16 \\
\hline Benzo[b]fluoranthene & $\mathrm{BbF}$ & 56.96 & 5.93 & 50.28 & 3.90 & 68.88 & 11.82 & 63.94 & 7.70 \\
\hline Benzo[k]fluoranthene & $\mathrm{BkF}$ & 17.26 & 0.76 & 14.45 & 1.20 & 21.26 & 3.79 & 18.82 & 1.56 \\
\hline Benzo[e]pyrene & $\mathrm{BeF}$ & 109.73 & 10.08 & 94.58 & 7.59 & 126.48 & 19.74 & 125.62 & 14.83 \\
\hline Benzo[a]pyrene & $\mathrm{BaF}$ & 42.46 & 6.06 & 40.38 & 2.87 & 47.70 & 9.19 & 38.41 & 4.01 \\
\hline Perylene & Pryl & 2.36 & 0.48 & 2.00 & 0.33 & 4.31 & 0.79 & 2.35 & 0.61 \\
\hline Indeno[1,2,3-cd]pyrene & IOP & 17.63 & 2.89 & 17.00 & 1.31 & 24.86 & 3.47 & 19.88 & 4.47 \\
\hline $\operatorname{Dibenz}[\mathrm{a}, \mathrm{h}$,$] anthracene$ & DA & 17.58 & 2.17 & 15.95 & 1.14 & 20.68 & 2.94 & 18.64 & 3.38 \\
\hline Benzo[g,h,i]perylene & BgP & 31.42 & 6.84 & 31.29 & 2.39 & 44.05 & 6.01 & 37.00 & 11.23 \\
\hline Coronene & Co & 2.04 & 2.10 & 3.87 & 0.59 & 4.36 & 0.94 & 3.73 & 3.08 \\
\hline
\end{tabular}


Table 3. PAH concentrations for parent compounds and alkylated homologues from humin extracts. Concentrations are given in $\mu \mathrm{g} / \mathrm{g}$ sediment with $\mathrm{n}=3$.

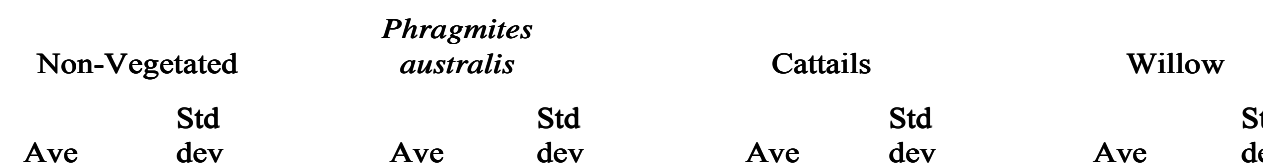

\begin{tabular}{|c|c|c|c|c|c|c|c|c|c|}
\hline Naphthalene & No & 0.07 & 0.01 & 0.09 & 0.03 & 0.09 & 0.02 & 0.05 & 0.01 \\
\hline Biphenyl & BP & & & 0.02 & 0.00 & 0.04 & 0.01 & 0.03 & 0.00 \\
\hline Acenaphthylene & ACL & 0.02 & 0.01 & 0.02 & 0.01 & 0.03 & 0.00 & 0.02 & 0.01 \\
\hline Acenaphthene & $\mathrm{ACE}$ & 0.01 & 0.00 & 0.01 & 0.00 & 0.03 & 0.01 & 0.01 & 0.00 \\
\hline Dibenzofuran & Dfu & 0.04 & 0.00 & 0.05 & 0.01 & 0.06 & 0.01 & 0.03 & 0.00 \\
\hline C1 - Naphthalenes & N1 & 0.08 & 0.00 & 0.09 & 0.03 & 0.12 & 0.02 & 0.07 & 0.01 \\
\hline C2 - Naphthalenes & $\mathrm{N} 2$ & 0.16 & 0.11 & 0.11 & 0.03 & 0.23 & 0.09 & 0.07 & 0.01 \\
\hline C3 - Naphthalenes & N3 & 0.14 & 0.03 & 0.15 & 0.03 & 0.36 & 0.11 & 0.10 & 0.01 \\
\hline C4 - Naphthalenes & N4 & 0.23 & 0.08 & 0.25 & 0.02 & 0.71 & 0.24 & 0.15 & 0.02 \\
\hline Fluorene & F0 & 0.10 & 0.04 & 0.07 & 0.01 & 0.12 & 0.02 & 0.05 & 0.02 \\
\hline C1 - Fluorenes & F1 & 0.20 & 0.03 & 0.20 & 0.04 & 0.53 & 0.15 & 0.15 & 0.03 \\
\hline C2 - Fluorenes & F2 & 0.38 & 0.09 & 0.41 & 0.18 & 1.18 & 0.38 & 0.31 & 0.05 \\
\hline C3 - Fluorenes & F3 & 0.37 & 0.12 & 0.37 & 0.24 & 1.27 & 0.35 & 0.38 & 0.10 \\
\hline Dibenzothiophene & Do & 0.21 & 0.07 & 0.32 & 0.07 & 0.26 & 0.04 & 0.12 & 0.03 \\
\hline C1 - Dibenzothiophene & D1 & 0.41 & 0.07 & 0.49 & 0.15 & 0.98 & 0.26 & 0.29 & 0.04 \\
\hline C2 - Dibenzothiophene & D2 & 0.59 & 0.21 & 0.64 & 0.32 & 1.61 & 0.57 & 0.50 & 0.09 \\
\hline C3 - Dibenzothiophene & D3 & 0.43 & 0.21 & 0.52 & 0.38 & 1.39 & 0.58 & 0.37 & 0.08 \\
\hline Anthracene & AN & 0.18 & 0.16 & 0.25 & 0.32 & 0.14 & 0.02 & 0.26 & 0.03 \\
\hline Phenanthrene & P0 & 0.32 & 0.02 & 0.49 & 0.15 & 0.51 & 0.07 & 0.27 & 0.03 \\
\hline C1 - Phenanthrenes/Anthracenes & $\mathbf{P 1}$ & 0.44 & 0.01 & 0.81 & 0.31 & 0.96 & 0.27 & 0.39 & 0.05 \\
\hline
\end{tabular}


Table 3 continued

$\begin{array}{llll}\text { Non-Vegetated } & \text { Phragmites australis } & \text { Cattails }\end{array}$

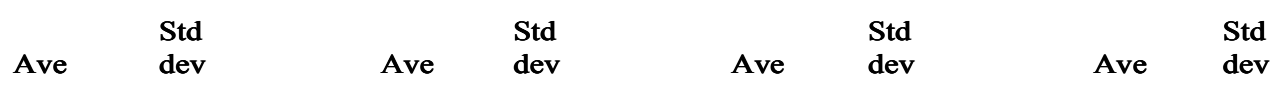

C2 - Phenanthrenes/Anthracenes

C3 - Phenanthrenes/Anthracenes

C4 - Phenanthrenes/Anthracenes

Fluoranthene

Pyrene

C1 - Fluoranthenes/Pyrenes

Retene

Benz[a]anthracene

Chrysene

C1 - Chrysenes

C2 - Chrysenes

C3 - Chrysenes

C4 - Chrysenes

Benzo[b]fluoranthene

Benzo[k]fluoranthene

Benzo[e]pyrene

Benzo[a]pyrene

Perylene

Indeno[1,2,3-cd]pyrene

Dibenz[a,h,]anthracene

Benzo[g,h,i]perylene

Coronene

\begin{tabular}{|c|c|}
\hline 0.67 & 0.14 \\
\hline 0.49 & 0.23 \\
\hline 0.11 & 0.03 \\
\hline 0.27 & 0.06 \\
\hline 0.97 & 0.33 \\
\hline 1.07 & 0.46 \\
\hline 0.30 & 0.07 \\
\hline 0.90 & 0.29 \\
\hline 0.71 & 0.33 \\
\hline 0.34 & 0.17 \\
\hline 0.11 & 0.08 \\
\hline 0.02 & 0.01 \\
\hline 0.36 & 0.22 \\
\hline 0.13 & 0.06 \\
\hline 0.87 & 0.53 \\
\hline 0.40 & 0.35 \\
\hline 0.01 & 0.01 \\
\hline 0.26 & 0.21 \\
\hline 0.15 & 0.13 \\
\hline 0.65 & 0.44 \\
\hline 0.16 & 0.06 \\
\hline
\end{tabular}

1.81

0.60

1.94

0.65

$0.58 \quad 0.09$

P3

FL

PY

FP1

$\mathrm{Re}$

$\mathrm{BaA}$

CO

C1

$\mathrm{C} 2$

C3

C4

$\mathrm{BbF}$

BkF

$\mathrm{BeF}$

$\mathrm{BaF}$

Pryl

IOP

DA

BgP

Co

$\begin{array}{llllll}1.81 & 0.60 & 1.94 & 0.65 & 0.58 & 0.09 \\ 1.26 & 0.82 & 1.75 & 0.61 & 0.46 & 0.10 \\ 0.25 & 0.24 & 0.43 & 0.16 & 0.14 & 0.01 \\ 0.35 & 0.20 & 0.62 & 0.16 & 0.25 & 0.05 \\ 0.99 & 0.48 & 2.11 & 0.66 & 0.80 & 0.06 \\ 1.64 & 0.09 & 2.60 & 0.85 & 0.92 & 0.06 \\ 0.44 & 0.29 & 0.71 & 0.25 & & \\ 1.14 & 0.27 & 2.09 & 0.73 & 0.29 & 0.06 \\ 0.63 & 0.32 & 1.87 & 0.72 & 0.79 & 0.04 \\ 0.27 & 0.15 & 1.08 & 0.40 & 0.65 & 0.11 \\ 0.08 & 0.06 & 0.43 & 0.16 & 0.32 & 0.07 \\ 0.01 & 0.01 & 0.11 & 0.09 & 0.11 & 0.04 \\ 0.29 & 0.20 & 0.61 & 0.18 & 0.01 & 0.01 \\ 0.16 & 0.17 & 0.34 & 0.13 & 0.28 & 0.02 \\ 0.59 & 0.28 & 1.61 & 0.48 & 0.17 & 0.06 \\ 0.22 & 0.22 & 0.59 & 0.20 & 0.68 & 0.07 \\ 0.02 & 0.03 & 0.11 & 0.06 & 0.21 & 0.03 \\ 0.16 & 0.09 & 0.54 & 0.18 & 0.01 & 0.01 \\ 0.08 & 0.04 & 0.37 & 0.15 & 0.23 & 0.03 \\ 0.36 & 0.17 & 1.15 & 0.32 & 0.14 & 0.03 \\ 0.08 & 0.06 & 0.33 & 0.08 & 0.54 & 0.12 \\ & & & & 0.15 & 0.03\end{array}$


Table 4. PAH concentrations for parent compounds and alkylated homologues from De-ashed humin extracts. Concentrations are given in $\mu \mathrm{g} / \mathrm{g}$ sediment with $\mathrm{n}=3$.

$$
\begin{array}{cc}
\text { Phragmites } \\
\text { Non-Vegetated }
\end{array}
$$

\begin{tabular}{|c|c|c|c|c|c|c|c|c|c|}
\hline & & Ave & $\begin{array}{l}\text { Std } \\
\text { dev }\end{array}$ & Ave & $\begin{array}{l}\text { Std } \\
\text { dev }\end{array}$ & Ave & $\begin{array}{l}\text { Std } \\
\text { dev }\end{array}$ & Ave & $\begin{array}{l}\text { Std } \\
\text { dev }\end{array}$ \\
\hline Naphthalene & No & 0.082 & 0.091 & 0.140 & 0.200 & 0.040 & 0.032 & 0.039 & 0.043 \\
\hline Biphenyl & BP & & & 0.134 & 0.027 & 0.013 & 0.008 & 0.012 & 0.010 \\
\hline Acenaphthylene & ACL & 0.000 & 0.000 & 0.010 & 0.007 & 0.004 & 0.002 & 0.005 & 0.001 \\
\hline Acenaphthene & ACE & 0.002 & 0.002 & 0.023 & 0.027 & 0.004 & 0.002 & 0.005 & 0.003 \\
\hline Dibenzofuran & Dfu & 0.003 & 0.005 & 0.063 & 0.050 & 0.024 & 0.017 & 0.025 & 0.020 \\
\hline C1 - Naphthalenes & N1 & 0.050 & 0.040 & 0.111 & 0.150 & 0.044 & 0.036 & 0.057 & 0.040 \\
\hline C2 - Naphthalenes & $\mathrm{N} 2$ & 0.041 & 0.038 & 0.166 & 0.197 & 0.068 & 0.052 & 0.109 & 0.035 \\
\hline C3 - Naphthalenes & N3 & 0.051 & 0.039 & 0.182 & 0.127 & 0.056 & 0.022 & 0.087 & 0.052 \\
\hline C4 - Naphthalenes & N4 & 0.062 & 0.032 & 0.037 & 0.064 & 0.068 & 0.008 & 0.044 & 0.046 \\
\hline Fluorene & F0 & 0.022 & 0.039 & 0.065 & 0.036 & 0.031 & 0.011 & 0.027 & 0.024 \\
\hline C1 - Fluorenes & $\mathrm{F} 1$ & 0.042 & 0.024 & 0.179 & 0.059 & 0.077 & 0.009 & 0.057 & 0.046 \\
\hline $\mathrm{C} 2$ - Fluorenes & $\mathrm{F} 2$ & 0.072 & 0.064 & 0.253 & 0.099 & 0.118 & 0.016 & 0.081 & 0.058 \\
\hline C3 - Fluorenes & F3 & 0.083 & 0.074 & 0.224 & 0.059 & 0.117 & 0.016 & 0.085 & 0.055 \\
\hline Dibenzothiophene & D0 & 0.067 & 0.059 & 0.400 & 0.100 & 0.141 & 0.024 & 0.096 & 0.090 \\
\hline C1 - Dibenzothiophene & D1 & 0.135 & 0.029 & 0.408 & 0.100 & 0.190 & 0.030 & 0.135 & 0.098 \\
\hline C2 - Dibenzothiophene & D2 & 0.162 & 0.086 & 0.309 & 0.202 & 0.227 & 0.020 & 0.173 & 0.089 \\
\hline C3 - Dibenzothiophene & D3 & 0.139 & 0.122 & 0.224 & 0.101 & 0.101 & 0.020 & 0.100 & 0.049 \\
\hline Anthracene & AN & 0.272 & 0.044 & 0.067 & 0.013 & 0.039 & 0.006 & 0.031 & 0.014 \\
\hline Phenanthrene & P0 & 0.061 & 0.054 & 0.821 & 0.311 & 0.249 & 0.054 & 0.191 & 0.153 \\
\hline C1 - Phenanthrenes/Anthracenes & P1 & 0.095 & 0.113 & 0.639 & 0.194 & 0.208 & 0.039 & 0.195 & 0.085 \\
\hline
\end{tabular}


Table 4 continued

$\begin{array}{llll}\text { Non-Vegetated } & \text { Phragmites australis } & \text { Cattails } & \text { Willow }\end{array}$

\begin{tabular}{|c|c|c|c|c|c|c|c|c|c|}
\hline & & Ave & $\begin{array}{l}\text { Std } \\
\text { dev }\end{array}$ & Ave & $\begin{array}{l}\text { Std } \\
\text { dev }\end{array}$ & Ave & $\begin{array}{l}\text { Std } \\
\text { dev }\end{array}$ & Ave & $\begin{array}{l}\text { Std } \\
\text { dev }\end{array}$ \\
\hline C2 - Phenanthrenes/Anthracenes & P2 & 0.159 & 0.095 & 0.481 & 0.128 & 0.250 & 0.028 & 0.213 & 0.089 \\
\hline C3 - Phenanthrenes/Anthracenes & P3 & 0.131 & 0.115 & 0.277 & 0.109 & 0.193 & 0.019 & 0.163 & 0.077 \\
\hline C4 - Phenanthrenes/Anthracenes & P4 & 0.076 & 0.067 & 0.044 & 0.039 & 0.042 & 0.002 & 0.033 & 0.018 \\
\hline Fluoranthene & FL & 0.098 & 0.144 & 0.176 & 0.035 & 0.103 & 0.010 & 0.071 & 0.050 \\
\hline Pyrene & PY & 0.134 & 0.052 & 0.438 & 0.131 & 0.270 & 0.030 & 0.188 & 0.130 \\
\hline C1 - Fluoranthenes/Pyrenes & FP1 & 0.239 & 0.014 & 0.511 & 0.195 & 0.302 & 0.020 & 0.232 & 0.127 \\
\hline Retene & $\operatorname{Re}$ & & & & & & & & \\
\hline Benz[a]anthracene & $\mathrm{BaA}$ & 0.188 & 0.054 & 0.188 & 0.026 & 0.107 & 0.003 & 0.079 & 0.038 \\
\hline Chrysene & $\mathrm{CO}$ & 0.200 & 0.195 & 0.466 & 0.087 & 0.382 & 0.010 & 0.262 & 0.143 \\
\hline C1 - Chrysenes & $\mathrm{C} 1$ & 0.424 & 0.294 & 0.340 & 0.098 & 0.287 & 0.002 & 0.305 & 0.150 \\
\hline C2 - Chrysenes & $\mathrm{C} 2$ & 0.129 & 0.048 & 0.137 & 0.049 & 0.132 & 0.006 & 0.295 & 0.321 \\
\hline C3 - Chrysenes & $\mathrm{C} 3$ & 0.036 & 0.032 & 0.023 & 0.040 & 0.028 & 0.010 & 0.243 & 0.355 \\
\hline C4 - Chrysenes & $\mathrm{C} 4$ & 0.003 & 0.005 & 0.007 & 0.007 & 0.000 & 0.000 & 0.089 & 0.077 \\
\hline Benzo[b]fluoranthene & $\mathrm{BbF}$ & 0.027 & 0.047 & 0.144 & 0.024 & 0.110 & 0.007 & 0.090 & 0.080 \\
\hline Benzo[k]fluoranthene & $\mathrm{BkF}$ & 0.152 & 0.192 & 0.023 & 0.003 & 0.023 & 0.002 & 0.099 & 0.140 \\
\hline Benzo[e]pyrene & $\mathrm{BeF}$ & 0.105 & 0.079 & 0.265 & 0.076 & 0.228 & 0.006 & 0.214 & 0.198 \\
\hline Benzo[a]pyrene & $\mathrm{BaF}$ & 0.121 & 0.098 & 0.100 & 0.046 & 0.055 & 0.007 & 0.050 & 0.061 \\
\hline Perylene & Pryl & 0.052 & 0.072 & 0.004 & 0.004 & 0.005 & 0.002 & 0.004 & 0.007 \\
\hline Indeno $[1,2,3-\mathrm{cd}]$ pyrene & IOP & 0.059 & 0.053 & 0.072 & 0.014 & 0.043 & 0.005 & 0.080 & 0.050 \\
\hline Dibenz $[a, h$,$] anthracene$ & $\mathrm{DA}$ & 0.033 & 0.031 & 0.038 & 0.007 & 0.025 & 0.003 & 0.073 & 0.071 \\
\hline Benzo[g,h,i]perylene & $\mathrm{BgP}$ & 0.075 & 0.019 & 0.153 & 0.048 & 0.132 & 0.017 & 0.207 & 0.144 \\
\hline Coronene & Co & 0.006 & 0.005 & 0.026 & 0.008 & 0.011 & 0.003 & 0.028 & 0.016 \\
\hline
\end{tabular}


Table 5. PAH Concentrations ${ }^{\mathrm{a}, \mathrm{b}}\left({ }^{ \pm} 1\right.$ Standard Deviation), Percent Total Organic Carbon $(\% \text { TOC })^{\mathrm{b}}$, and Percent Modern Carbon ${ }^{\mathrm{b}}\left({ }^{14} \mathrm{C}\right.$ PMC) Content for Vegetated and NonVegetated Indiana Harbor Sediment Fractions.

\section{Non- Phragmites Cattails Willow Vegetated Trees}

\section{Bulk Sediment}

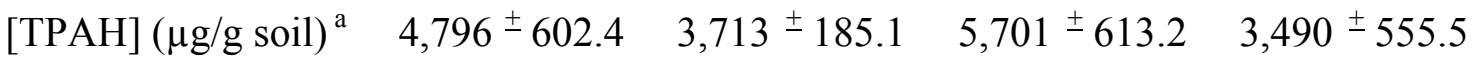

$[16 \mathrm{PAH}](\mu \mathrm{g} / \mathrm{g}$ soil $) \quad 1,205^{ \pm} 124.7 \quad 942 \pm 62.94 \quad 1,421 \pm 51.89 \quad 890 \pm 53.5$

$[\mathrm{TPAH}]\left(\mu \mathrm{g} / \mathrm{g}\right.$ OC) $\quad 33,500 \pm 6,450 \quad 26,900{ }^{ \pm} 1,610 \quad 16,600{ }^{ \pm} 2,340 \quad 16,000 \pm 3,554$

\section{Humin}

$[\mathrm{TPAH}](\mu \mathrm{g} / \mathrm{g} \text { soil })^{\text {a }} \quad 13.3^{ \pm} 4.50 \quad 16.2 \pm 4.47 \quad 38.6^{ \pm} 3.20 \quad 11.4^{ \pm} 0.811$

$[16 \mathrm{PAH}](\mu \mathrm{g} / \mathrm{g}$ soil $) \quad 4.22^{ \pm} 1.25 \quad 3.81^{ \pm} 0.602 \quad 12.0{ }^{ \pm} 0.645 \quad 4.47 \pm 0.163$

[TPAH] $(\mu \mathrm{g} / \mathrm{g}$ OC $) \quad 253 \pm 96.3 \quad 482 \pm 143 \quad 640 \pm 75.9 \quad 159 \pm 17.5$

\section{De-Ashed Humin}

$[\mathrm{TPAH}](\mu \mathrm{g} / \mathrm{g} \text { soil })^{\mathrm{a}} \quad 3.88 \pm 0.337 \quad 8.37 \pm 2.30 \quad 4.54{ }^{ \pm} 0.320 \quad 4.57 \pm 1.76$

$[16 \mathrm{PAH}](\mu \mathrm{g} / \mathrm{g}$ soil $) \quad 1.61 \pm 0.790 \quad 2.54{ }^{ \pm} 0.304 \quad 1.66^{ \pm} 0.165 \quad 1.76^{ \pm} 0.511$

$[\mathrm{TPAH}](\mu \mathrm{g} / \mathrm{g}$ OC $) \quad 81.2 \pm 9.88 \quad 192 \pm 2.92 \quad 95.5^{ \pm} 18.7 \quad 146 \pm 27.3$

\footnotetext{
${ }^{a}$ Total alkylated and non-alkylated PAH $(n=42)$ concentrations of lipid extracts from sediment fractions analyzed at NCSU.

${ }^{\mathrm{b}}$ Values are mean \pm one standard deviation $(\mathrm{n}=3)$.
} 


\section{DISCUSSION}

A variety of field and greenhouse studies have explored the role of vegetation in PAH dissipation, with a variety of results. Previously, we discussed that PdOC may enhance rates of PAH degradation by stimulating microbial activity and/or by increasing PAH bioavailability in the rhizosphere. In this study, actual dissipation of PAH is difficult to detect strictly by PAH contaminant levels. This is not surprising given the extremely high concentrations of PAH and the short timeframe of vegetation colonization. In this case, the best indicators of PAH dissipation and the impacts of vegetation and PdOM flux come from weathering indices and radiocarbon PMC measurements.

The divergence of mass sediment and carbon normalized [TPAH] data in humin fractions from bulk sediments TPAH data does not reflect greater organic carbon content in these fractions. The \% TOC for the different sediment fractions is shown in Figure 2. Greater carbon-normalized TPAH concentrations for humin fractions of Phragmites, cattail, and willow trees do not occur in conjunction with notable increases in \% TOC.

Greater organic carbon content did not explain increased TPAH concentrations in sediments fractions containing plant detrital material (Rockne et al., 2002). Equilibrium aqueous-solid partitioning data showed that sediment fractions with plant detrital material were stronger, preferential sorbents for PAH sequestration and partitioning than sediment fractions without plant materials. The authors speculated that as PAHs partition from various organic matter-rich regions in sediments aggregates, they reversibly partitioned into sediment material rich in plant, vascular debris. Thus, greater PAH concentrations in cattail 
humin and Phragmites de-ashed humin may result from PAH sequestration and partitioning into plant derived materials in these sediment fractions.

Rockne et al. (2002) and Shor et al., (2003) observed that sediment fractions with plant detrital material and high $\mathrm{PAH}$ concentrations disproportionately impacted high molecular weight PAH desorption and more extensively desorbed all PAHs than sediment fractions without detrital material. These authors stressed the important role of plant material as a preferential sorbent in sediments where other geosorbents such as soot are not the primary source of PAHs to sediments.

Carbon isotopic techniques have been used to trace PdOC cycling in rhizosphere sediment (Reid, 1974, 1977; Cheng et al. 1993) and can be used to determine if correlations exist between enhanced PAH attenuation and PdOC inputs. ${ }^{14} \mathrm{C}$ measurements quantitatively track new plant carbon inputs into both refractory and labile sedimentary compartments, as both low molecular weight exudates and high molecular weight root structures have modern carbon signatures. Interestingly, all three vegetated humin fractions contain more modern carbon than non-vegetated humin (Figure 2; (Dunnett's ANOVA, $p<$ 0.05). This trend is not observed in bulk sediment fractions and is less apparent in de-ashed humin fractions. Increased modern carbon content for Phragmites and cattails humin (Figure 2) is related to greater carbon-normalized TPAH concentrations (Table 6), but only Phragmites humin shows a relationship between increased modern carbon and more weathered $\mathrm{N}_{3} / \mathrm{P}_{2}$ ratios.

Phragmites australis is considered an invasive species, but it is also a useful model plant to study because of its tolerance to anthropogenic contamination and physiological characteristics. Phragmites australis is known for its translocation of oxygen and carbon 
from plant shoots/leaves to sediments via its roots (Minchinton, 2002). Nearly 50\% of its litter becomes substrate material for soils and sediments and the majority of its biomass is non-grazed (Asaeda et al, 2002). Total organic acid concentrations in pore water of both deep water and land stands of Phragmites australis average 1,100-1,600 $\mu \mathrm{mol} / \mathrm{L}$, and are predominantly acetic, citric, tartaric, and malic acids (Cizkova et al., 1999). These attributes, no doubt, contribute to Phragmites' success and tolerance of saturated (Armstrong and Armstrong, 2001), metal-contaminated (Yea et al., 2003), saline (Chambers et al., 1998), and eutrophic environments (Lin et al., 2002). Likewise, these characteristics may explain the increased amounts of plant carbon present in Phragmites sediments. 


\section{CONCLUSION}

Plants both aerate the soil, encouraging volatilization, and release PdOM, which modifies the sediment matrix. Both of these processes are likely to have an impact on PAH contamination, but untangling the role of PdOC inputs and fluxes in sediments is not a trivial matter. This study shows alteration of sediment composition in bulk and humin sediment fractions after 2 years of plant growth in fuel-oiled sediments. Mass normalized TPAH concentrations did not decline in vegetated sediments relative to non-vegetated sediments. Carbon-normalized TPAH concentrations were significantly lower in vegetated bulk sediments but higher in humin fractions. Percent TOC data could not be used to estimate PAH concentrations, modern carbon (plant carbon) accumulation, or PAH weathering in vegetated sediments fractions relative to non-vegetated sediments. Significant increases in percent modern carbon measurements did relate to greater $\mathrm{N}_{3} / \mathrm{P}_{2}$ weathering in vegetated bulk and humin fractions. These data show that Phragmites accumulates more plant carbon in sediment fractions than cattails or willow trees and that this accumulation results in greater weathering of two and three ring PAHs. The fact that modern carbon is present in humin and de-ashed humin at such measured levels after 2 years of plant growth is important to PAH carbon turnover and biogenic carbon cycling processes. 


\section{FUTURE WORK}

Fractionation of sediments into functionally different carbon pools has been done several times in recent studies (Grunewald et al., 2006; Sollins et al., 1996; Helfrich et al. 2006; Oren and Chefez, 2005) in order to probe the characteristics and functionality of sediment components. Density fractionation, in particular, allows the separation of carbon pools in a simple manner (Swanston et al., 2005; Ghosh et al., 2001; Golchin et al., 1997); whereas, chemical fractionation separates the most recalcitrant SOM from mineral fractions. Light fractions of sediments appear to be the most responsive to new organic carbon inputs and least well protected in terms of sequestering carbon. Heavy density fractions are associated with mineral matrices and tend to be lower in organic carbon and contain the oldest, most recalcitrant carbon pool. There is some evidence that the heavy density fraction contains a small pool of more labile carbon (Chotte et al., 1998), but the bulk of the rapidly cycling carbon resides in the light density fraction.

Radiocarbon analyses show that light density fractions are younger and less recalcitrant than heavy density fractions; heavy density fractions tend to have a lower proportion of biogenic new carbon and are associated with inorganic fractions. PAH degradation varies among sediment fractions and particle types. Bioslurry experiments with density fractions from PAH-contaminated sediments showed that PAH availability and associated degradation rates were greatest in heavier density fractions (Talley et al., 2002) where the primary organic particle type was coal derived and highly aromatic (Ghosh, et al., 2003; Talley et al., 2002). Conversely, degradation rates were shown to be greatest in lighter fractions when the primary particle type was a pitch mixture. 
Physical separation of carbon pools can provide important information on the PAH content and sorptive properties of some compartments. This information is useful to understand the behavior of PAH carbon in SOM; however, physical separations do not directly measure the impact of PdOC on sedimentary carbon cycling. Though the majority of recent PdOC inputs will reside in lighter density fractions, these fractions also contain other sediment constituents as well. In order to more directly explore PdOC, it is necessary to use chemical fractionation to separate known fractions of PdOC. Physical and Chemical fractionation of sediments in conjunction with desorption and $\mathrm{K}_{\mathrm{oc}}$ experiments would give a greatly enhanced understanding of the impact of vegetation on PAH contaminated sediments. 


\section{REFERENCES}

Accardi-Dey, A., Gschwend, P.M. 2002. Assessing the Combined Roles of Natural Organic Matter and Black Carbon as Sorbents in Sediments. Environ. Sci. Technol., 36, $21-29$.

Alvarez-Bernal, D., Contreras-Ramos, S., Marsch, R., Dendooven, L. 2007. Influence of catclaw mimosa monancistra on the dissipation of soil PAHs. Int. J. Phytorem. 9, 7990.

Anderson, T.A., E.A. Guthrie, and B.T. Walton. 1993. Bioremediation in the rhizosphere-Plant roots and associated microbes clean contaminated soil. Environ. Sci. Technol. 27, 2630-2636.

Aprill, W., Sims, R.C. 1990. Evaluation of the use of prairie grasses for stimulating polycyclic aromatic hydrocarbon treatment in soil. Chemosphere 20, 253-265.

Armstrong, J., Armstrong, W. 2001. An overview of the effects of phytotoxins on phragmites australis in relation to die-back. Aquatic Botany 69, 251-268.

Asaeda, T., Nam, L., Hietz, P., Tanaka, N., Karunaratne, S. 2002. Seasonal fluctuations in live and dead biomass of phragmites australis as described by a growth and decomposition model, implications of duration of aerobic conditions for litter mineralization and sedimentation. Aquatic Botany 73, 223-239.

Banks, M.K., Lee, E., Schwab, A.P. 1999. Evaluation of dissipation mechanisms for benzo[a]pyrene in the rhizosphere of tall fescue. J. Environ. Qual. 28, 294-298. 
Barber, D.A., Lynch, J.M. 1977. Microbial Growth in the Rhizosphere. Soil Biol. Biochem. 9, 305-308

Binet, Ph., Portal, J.M., Leyval, C. 2000. Fate of Polycyclic Aromatic Hydrocarbons (PAH) in the Rhizosphere and Mycorrhizosphere of Ryegrass. Plant and Soil. 227, 207-213.

Brix, H., Sorrell, B.K., Lorenzen, B. 2001. Are Phragmites-dominated wetlands a net source or net sink of greenhouse gasses? Aquatic Botany, 69, 313-324.

Brogan, B.W., Sullivan, W.R. 2003. Physicochemical soil parameters affecting sequestration and mycobacterial biodegradation of polycyclic aromatic hydrocarbons in soil. Chemosphere, 52, 1717-1726.

Cavalieri, E.L.; Rogan, E.G.; Cremonesi, P.; Devanesan, P.D. 1988. Radical cations as precursors in the metabolic formation of quinones from benzo[a]pyrene and 6fruorobenzo[a]pyrene : fluorosubstitution as a probe for one-electron oxidation in aromatic sustrates. Biochem. Pharm. 37, 2173-2182.

Chambers, R., Mozdzer, T., Ambrose, J. 1998. Effects of salinity and sulfide on the distribution of phragmites australis andsSpartina alterniflora in a tidal salt marsh. Aquatic Botany 62, 161-169.

Carter, M.C., Weber, W.J., 1994. Modeling adsorption of TCE by activated carbon rreloaded by background organic matter. Environ. Sci. Technol. 28, 614-623. 
Chefetz, B., Deshmukh, A. P., Hatcher, P. G., Guthrie, E. A. 2000. Pyrene sorption by natural organic matter. Environ. Sci. Technol. 34, 2925-2930.

Chen, B., Johnson, E.J., Chefetz, B., Lizhong, Z., Xing, B. 2005. Sorption of polar and nonpolar aromatic organic contaminants by plant cuticular materials: role of polarity and accessibility. Environ. Sci. Technol. 39, 6138-6146.

Cheng, W., Coleman, D.C., Carrol, R., Hoffman, C.A. 1993. InSitu Measurements of Root Respiration and Soluble C Concentrations in the Rhizosphere. Soil Biol. Biochem. 25, 1189-1196.

Cizkova, H., Brix, H., Kopecky, J., Kukavska, J. 1999. Organic acids in the sediments of wetlands dominated by phragmites australis, evidence of phytotoxic concentrations. Aquatic Botany 64, 303-315.

Corgié, S.C., Beguiristain, T., Leyval, C. 2004. Spatial distribution of bacterial communities and phenanthrene degradation in the rhizosphere of lolium perenne L. Appl. Environ. Microbiol. 70, 3552-3557.

Davies, L.C., Carias, C.C., Novais, J.M., Martins-Diaz, S. 2005. Phytoremdiation of Textile Effluents Containing Azo Dye by using Phragmites australus in a vertical flow intermittent feeding constructed wetland. Ecological Engineering, 25, 594-605.

Davis, L.C., Castro-Diaz, S., Zhang, Q., Erickson, L.E. 2002. Benefits of Vegetation for Soils with Organic Contaminants Crit. Rev. Plant Sci. 21, 457-491. 
Dexter, R.N., Pavlou, S.P. 1978. Distribution of stable organic molecules in the marine environment: physical-chemical aspects; chlorinated hydrocarbons. Mar. Chem. 7, 6784.

Doick, K.J., Klingelmann, E., Burauel, P., Jones, K.C., Semple, K.T. 2005. Long-term fate of polycyclic aromatic hydrocarbons in an agricultural soil. Environ. Sci. Technol. 39, 3663-3670.

Douglas, G.S., Bence, A.E., Prince, R.C., McMillen, S.J., Butler, E.L. 1996. Environmental stability of selected petroleum hydrocarbon source and weathering ratios. Environ. Sci. Technol. 30, 2332-2339.

Dunnett, C.W. 1955. A multiple comparison procedure for comparing several treatments with a control. J. Am. Stat. Assoc. 272, 1096-1121.

Dunnett, C.W. 1964. New tables for multiple comparisons with a control. Biometrics 20, $482-491$.

Durant, J.L., Lafleur, A.L., Busby, W.F., Donhoffner, J.L., Penman, B.W., Crespi, C.L. 1999. Mutagenicity of C24H14 PAH in human cells expressing Cyp1A1. Mutation. Research/GeneticToxicology and Environmental Mutagenesis. 446, 1-14.

Durant, J.L., Busby, W.F., Lafleur, A.L., Penman, B.W., Crespi, C.L. 1996, Human cell mutagenicity of oxygenated, nitrated and unsubstituted polycyclic aromatic hydrocarbons associated with urban aerosols. Mutation. Research/GeneticToxicology and Environmental Mutagenesis. 371, 123-157. 
Ehlers, L.J., Luthy, R.G. 2003. Contaminant Bioavalability in Soil and Sediment. Environ. Sci. Technol. A-Pages. 37, 295A-302A.

Erickson, D.C., Loerhr, R.C., Neuhauser, E.F. 1993. PAH loss during bioremediation of manufactured gas plant site soils Water Res. 27, 911-919.

Fernandes, M.B., Brooks, P. 2003. Charachterization of Carbonaceous Combustion Residues: II. Nonpolar Organic Compounds, Chemosphere, 53, 447-458.

Grayston, S.J., Vaughan, D., Jones, D. 1996. Rhizosphere carbon flow in trees, in comparison with annual plants: the importance of root exudation and its impact on microbial activity and nutrient availability. Applied Soil Ecology, 5, 29-56.

Gregory, S.T., Shea, D., Nichols-Guthrie, E. 2005. Impact of vegetation on sedimentary organic matter composition and polycyclic aromatic hydrocarbon attenuation. Environ. Sci. Technol. 39, 5285-5292.

Guthrie, E.A., Bortiatynski, J.M., van Heemst, J.D.H., Richman, J.E., Hardy, S.K., Kovach, E.M., Hatcher, P.G. 1999. Determination of $\left[{ }^{13} \mathrm{C}\right]$ pyrene sequestration in sediment microcosms using flash pyrolysis-GC-MS and ${ }^{13} \mathrm{C}$ NMR. Environ Sci Technol. 33, 119-125.

Hatzinger, P.B., Alexander, M. 1995. Effect of aging of chemicals in soil on their biodegradability and extractability. Environ. Sci. Technol. 29, 537-545. 
Hong, L., Ghosh, U., Mahajan, T., Zare, R. N., Luthy, R. G. 2003. PAH Sorption mechanism and partitioning behavior in lampblack-impacted soils from former oil-gas plant sites Environ. Sci. Technol., 37, 3625-3634.

Hundal, L. S., Thompson, M. L., Laird, D. A., Carmo, A. M. 2001. Sorption of Phenanthrene by Reference Smectites. Environ. Sci. Technol. 35, 3456-3461.

Husain, S.S., McKeen, W.E. 1963. Interactions between strawberry roots and Rhizoctonia fragariae. Phytopathology, 53, 541-54.

Jouanneau, Y., Willison, J.C., Meyer, C., Krivobok, S., Chevron, N., Besombes, J., Blake, G. 2005. Stimulation of pyrene mineralization in freshwater sediments by bacterial and plant bioaugmentation. Environ. Sci. Technol. 39, 5729-5735.

Kamath, R., Schnoor, J.L., Alvarez, P.J.J. 2005. A model for the effect of rhizodeposition on the fate of phenanthrene in aged contaminated soil. 2005. Environ. Sci. Technol. 39, 9669-9675.

Kögel-Knabner, I., Ziegler, F. 1993. Carbon distribution in different compartments of forest soils. Geoderma, 56, 515-525.

Kohl, S.D., Rice, J.A. 1998. The binding of contaminants to humin: A mass balance Chemosphere 36, 251-261

Kummerova, M., Kmentova, E. 2004. Photoinduced Toxicity of Fluoranthene on Germination and early Development of Plant Seedlings. Chemosphere, 56, 387-393. 
Kukkonen, J.V.K., Landrum, P.F., Mitra, S., Gossiaux, D.C., Gunnarsson, J., Weston, D. 2003. Sediment characteristics affecting desorption kinetics of select PAH and PCB congeners for seven laboratory spiked sediments. Environ. Sci. Technol. 37, 46564663.

Lalande, T.L., Skipper, H.D., Wolf. D.C., Reynolds, C.M., Freedman, D.L., Pinkerton, B.W., Hartel, P.G., Grimes, L.W. 2003. Phytoremediation of pyrene in a cecil soil under field conditions. Int. J. Phytorem. 5, 1-12.

Leyval, C., Berthelin, J. 1993. Rhizodeposition and Net Release of Soluble Organic Compounds by Pine and Beech seedlings inoculated with rhizobacteria and ectomycorrhizal Fungi. Biol. Fertil. Soils, 15, 259-267.

Lin, Y., Jing, S., Wang, T., Lee, D. 2002. Effects of macrophytes and external carbon sources on nitrate removal from groundwater in constructed wetlands. Environ. Pollution. 119, 413-420.

Lissner, J., Schierup, H.H. 1997. Effects of salinity on the growth of Phragmites australis Aquatic Botany, 55, 247-260.

Liste, H., Alexander, M. 2000. Plant-promoted Pyrene Degradation in Soil. Chemosphere. 40, 7-10

Liste, H., Prutz, I. 2006. Plant performance, dioxygenase-expressing rhizosphere bacteria, and biodegradation of weathered hydrocarbons in contaminated soil. Chemosphere. 62 , 1411-1420. 
Luellen, D.R. ,Shea, D. 2002. Calibration and field verification of semipermeable membrane devices for measuring polycyclic aromatic hydrocarbons in water. Eniron. Sci. Technol. 36, 1791-1797.

Luthy, R.G., Aiken, G.R., Brusseau, M.L., Cunningham, S.D., Gschwend, P.M., Pignatello, J.J., Reinhard, M., Traina, S.J., Weber, W.J., Westall, J.C. 1998. Sequestration of hydrophobic organic contaminants by geosorbents. Environ. Sci. Technol. 31, 3341-3347.

Maila, M.P., Randima, P., Cloete, T.E. 2005. Multispecies and monoculture rhizoremediation of polycyclic aromatic hydrocarbons (PAHs) from the soil. Int. J. Phytorem. 7, 87-98.

Mao, J.D., Hundal, L.S., Thompson, M.L., Schmidt-Rohr, K. 2002. Correlation of poly(methylene)-rich amorphous aliphatic domains in humic substances with sorption of a nonpolar organic contaminant, phenanthrene. Environ. Sci. Technol. 36, 929-936.

Marr, L.C.,Booth, E.C., Andersen, R.G., Widdoson, M.T., Novak, J.T. 2006. Direct volatilization of napthalene to the atmosphere at a phytoremediation Site. Environ. Sci. Technol. 40, 5560-5566.

Meharg, A.A., Killham, K. A. 1998. Comparison of Carbon Flow from Pre-labeled and Pulse-labeled plants. Plant Soil 112, 225-231.

Michealian, K.H., Freisen, W.I. 1990. Photoacoustic FT-i.r. spectra of separated western Canadian coal macerals. Analysis of the $\mathrm{CH}$ stretching region by curve fitting and deconvolution. Fuel 69, 1271-1275. 
Michinton, T. 2002. Disturbance by wrack facilitates spread of phragmites australis in a coastal marsh. J. Exp. Mar. Biol. Ecol. 281, 89-107.

Miya, R.K., Firestone, M.K. 2001. Enhanced phenanthrene biodegradation in soil by slender oat root exudates and root debris. J. Environ. Qual. 30, 1911-1918.

Mueller, K.E., Shann, J.R. 2006. PAH Dissipation in spiked soil; impacts of bioavailability, microbial activity, and trees. Chemosphere 6, 1006-1014.

Murphy, E.M., Zachara, J.M., Smith, S.C. 1990. Influence of mineral-bound humic substances on the sorption of hydrophobic organic compounds. Environ. Sci. Technol. 24, 1507-1516.

Murphy, E.M., Zachara, J.M., Smith, S.C., Phillips, J.L. 1992. The sorption of humic acids to mineral surfaces and their role in contaminant binding. Sci. Total Environ. 117/118, 413-423.

Musella, J.S. 2006. Impact of plant organic matter on PAH desorption from petrogenicpolluted sediments. MSc Thesis. North Carolina State University. Raleigh, NC.

Neiman, J.K.C., Kimball, D.O., McLean, J.E., Sims, R.C., Sims, J.L., Sorensen, D.L., Rice, J.A. 1998. Humification of Pyrene in contaminated soil durin land farming Proceedings of the 1998 Conference on Hazardous Waste Research. 252-260.

Painter, P.C., Snyder, R.W., Starinic, M. Coleman, M.M., Kuehn, D.W., Davis, A. 1981. Concerning the Application of FT-IR to the Study of Coal: A Critical Assessment of 
Band Assignments and the Application of Spectral Analysis Programs. Appl. Spec, 35, 478.

Pan, B., Xing, B.S., Liu, W.X., Tao, S., Lin, X.M., Zhang, X.M., Zhang, Y.X., Xiao, Y., Dai, H.C., Yuan, H.S. 2006. Distribution of sorbed phenanthrene and pyrene in different humic fractions of soils and importance of humin. Environ Pollut. 143, 24-33.

Park, J., Zhao, X, Voice, T.C. 2005. Biodegradation of non-desorble naphthalene in soils. Environ. Sci. Technol. 35, 2734-2740.

Pignatello, J.J. Soil organic matter as a nanoporous sorbent of organic pollutants. 1998. Adv. Colloid Interface Sci. 77, 445-467.

Pitterle, M.T., Andersen, R.G., Novak, J.T., Widdowson, M.A. 2005. Push-pull tests to quantify in situ degradation rates at a phytoremediation site. Environ. Sci. Technol. 39, 9317-9323.

Raaijmakers, J.M., Weller, D.W., Thomashow, L.S. 1997. Frequency of AntibioticProducing Pseudomonas spp. in Natural Environments Appl. Environ. Microbiol. 63, $881-887$.

Ravit, B., Ehenfeld, J.G., Haggblom, M.M. 2006. Effects of Vegetation on Rootassociated Microbial Communities: A Comparison of Disturbed Versus Undisturbed Estuarine Sediments. Soil Biol. Biochem.

Reid, C.P.P. 1974. Assimilation, distribution, and root exudation of ${ }^{14} \mathrm{C}$ by ponderosa pine seedlings under induced water stress. Plant Physiol, 54, 44-49. 
Reid, C.P.P., Mexal, J.G. 1977. Water Stress on Root exudation by Lodgepole Pine. Soil Biol Biochem. 9, 417-422

Rockne, K.J., Shor, L.M., Young, L.Y., Taghon, G.L., Kosson, D.S. 2002. Distributed sequestration of PAHs in weathered sediment: the role of sediment structure and organic carbon properties. Environ. Sci. Technol. 36, 2636-2644.

Ryan, J.A., Bell, R.M., Davidson, J.M., O’Connor, G.A. 1988. Plant Uptake of non-ionic organic chemicals from soils. Chemosphere, 17, 2299-2323.

Salloum, M., Chefetz, B., Hatcher, P. G. 2002. Phenanthrene sorption by aliphatic-rich natural organic matter. Environ. Sci. Technol. 36, 1953-1958.

Sand Creek Consultants, Inc. 2002. Indiana harbors canal phytoremediation treatability study Year End Report (2002). 46 pages.

Sachleben, J.R., Chefetz, B., Deshmukh, A., Hatcher, P.G. 2004. Solid-State NMR Charachterization of Pyrene-Cuticular Matter Interactions Environ. Sci. Technol. 38, $4369-4376$.

Semple, K.T., Doick, K.J., Jones, K.C., Burauel, P., Craven, A., Harms, H. 2004. Defining Bioavalability and Bioaccessibility of Contaminated Soil and Sediment is Complicated. Environ. Sci. Technol. A-Pages. 38, 228A-231A.

Shimp, J. F., Tracy, J. C., Davis, L., Lee, E., Huang, W., Erickson, L.E., and Schnoor, J. L. 1993. Beneficial effects of plants in the remediation of soil and groundwater contaminated with organic materials. Crit Rev Environ Sci Technol. 23, 41-77. 
Silverstein, R.M., Bassler, G.C. Morril, T.C. Spectrometric identification of organic compounds. $5^{\text {th }}$ ed. New York; Wiley, (1991)

Shor, L., Rockne, K., Taghon, G., Young, L., Kosson, D. 2003. Desorption kinetics for field-aged polycyclic aromatic hydrocarbons from sediments. Environ. Sci. Technol. $37,1535-1544$.

Schwab, A.P., Banks, M.K. 1994. Biologically mediated dissipation of polyaromatic hydrocarbons in the root zone. p. 132-141. In Bioremediation through rhizosphere technology. Am. Chem. Soc., Washington, DC.

Smith, W.H. 1976. Character and significance of forest tree root exudates Ecology, 57, 324,331

Spriggs, T., Banks, M.K., Schwab, P. 2005. Phytoremediation of polycyclic aromatic hydrocarbons in manufactured gas plant-impacted soil. J. Environ. Qual. 34, 17551762.

Stevenson, F.J. (1982). Humus Chemistry John Wiley \& Sons, New York

Stuiver, M., Polach, H.A. 1977. Discussion : Reporting of ${ }^{14} \mathrm{C}$ data. Radiocarbon 19, 355363.

Tissot, B., Hood, G.D. 1978. Geochemical Study of the Uinta Basin: Formation of Petroleum from the Green River formation. Geochim Cosmochim, 42, 1469-1485. 
Thoma, G., Lam, T., Zeigler, S., Wolf, D. "Novel Approach to Measurement of Rhizosphere Effect in Phytoremediation" $3^{\text {rd }}$ International Phytotechnologies Conference, Atlanta, GA. April $19^{\text {th }}, 2005$

USEPA (U.S. Environmental Protection Agency). SW-846 Manual for Waste Testing Volumes 1B and 1C. Washington, DC. 1986.

Windham, L., Weis, J.S., Weis, P. 2001. Lead Uptake, Distribution, and Effects in Two Dominant Salt Marsh Macrophytes, Spartina alterniflora (Cordgrass) and Phragmites australis (Common Reed) Marine Pollution Bulletin, 42, 811-816.

White, J.C., Mattina, J.I., Lee, W., Eitzer, B.D., Iannucci-Berger, W. 2003. Role of Organic Acids in Enhancing the desorption and uptake of weathered $p, p^{\prime}$-DDE by Cucurbita pepo. Environmental Pollution, 124, 71-80

Widdowson, M.A., Shearer, S., Andersen, R.G., Novak, J.T. 2005. Remediation of polycyclic aromatic hydrocarbon compounds in groundwater using poplar trees Environ. Sci. Technol. 39, 1598-1605.

Ye, Z.H., Baker, A., Wong, M.,Willis, A. 2003. Copper tolerance, uptake and accumulation by phragmites australis. Chemosphere 50, 795-800. 